\title{
CHALLENGES AND STRATEGIES IN THE REPAIR OF RUPTURED ANNULUS FIBROSUS
}

\author{
Clare C. Guterl ${ }^{1,9}$, Eugene Y. See ${ }^{2,9}$, Sebastien B.G. Blanquer ${ }^{3,9}$, Abhay Pandit ${ }^{2,9}$, Stephen J. Ferguson ${ }^{4,9}$, Lorin M. \\ Benneker ${ }^{5,9}$, Dirk W. Grijpma ${ }^{3,7,9}$, Daisuke Sakai ${ }^{6,9}$, David Eglin ${ }^{8,9}$, Mauro Alini ${ }^{8,9}$, \\ James C. Iatridis ${ }^{1,9}$ and Sibylle $\mathrm{Grad}^{8,9 *}$
}

\author{
${ }^{1}$ Department of Orthopaedics, Mount Sinai Medical Centre, New York, NY, USA \\ ${ }^{2}$ Network of Excellence for Functional Biomaterials, National University of Ireland, Galway, Ireland \\ ${ }^{3}$ Department of Biomaterials Science and Technology, University of Twente, Enschede, The Netherlands \\ ${ }^{4}$ Institute for Biomechanics, ETH Zurich, Zurich, Switzerland \\ ${ }^{5}$ Department of Orthopaedic Surgery, University of Bern, Bern, Switzerland \\ ${ }^{6}$ Department of Orthopaedic Surgery, Tokai University School of Medicine, Isehara, Kanagawa, Japan \\ ${ }^{7}$ Department of Biomedical Engineering, University Medical Centre Groningen and University of Groningen, \\ Groningen, The Netherlands \\ ${ }^{8}$ AO Research Institute Davos, Davos, Switzerland \\ ${ }^{9}$ Collaborative Research Partner Annulus Fibrosus Rupture Program of AO Foundation, Davos, Switzerland
}

\begin{abstract}
Lumbar discectomy is the surgical procedure most frequently performed for patients suffering from low back pain and sciatica. Disc herniation as a consequence of degenerative or traumatic processes is commonly encountered as the underlying cause for the painful condition. While discectomy provides favourable outcome in a majority of cases, there are conditions where unmet requirements exist in terms of treatment, such as large disc protrusions with minimal disc degeneration; in these cases, the high rate of recurrent disc herniation after discectomy is a prevalent problem. An effective biological annular repair could improve the surgical outcome in patients with contained disc herniations but otherwise minor degenerative changes. An attractive approach is a tissue-engineered implant that will enable/stimulate the repair of the ruptured annulus. The strategy is to develop three-dimensional scaffolds and activate them by seeding cells or by incorporating molecular signals that enable new matrix synthesis at the defect site, while the biomaterial provides immediate closure of the defect and maintains the mechanical properties of the disc. This review is structured into (1) introduction, (2) clinical problems, current treatment options and needs, (3) biomechanical demands, (4) cellular and extracellular components, (5) biomaterials for delivery, scaffolding and support, (6) pre-clinical models for evaluation of newly developed cell- and material-based therapies, and (7) conclusions. This article highlights that an interdisciplinary approach is necessary for successful development of new clinical methods for annulus fibrosus repair. This will benefit from a close collaboration between research groups with expertise in all areas addressed in this review.
\end{abstract}

Keywords: Annulus fibrosus rupture; disc herniation; disc biomechanics; biomaterial scaffold; pre-clinical model; interdisciplinary approach; annulus fibrosus tissue engineering; annulus fibrosus regeneration.

*Address for correspondence:

Sibylle Grad, PhD

AO Research Institute Davos

Clavadelerstrasse 8

7270 Davos, Switzerland
Telephone Number: +41 814142480

FAX Number: +41814142288

E-mail: sibylle.grad@aofoundation.org

\section{Introduction}

Intervertebral disc (IVD) herniation is a common condition that frequently affects the spine of young and middle-aged patients. The IVD is a complex structure composed of different but interrelated tissues: the central gelatinous highly hydrated nucleus pulposus (NP), the surrounding fibres of the annulus fibrosus (AF), and the cartilaginous endplates that connect these tissues to the vertebral bodies. The extracellular network of collagens and proteoglycans is maintained by sparse populations of cells with generally fibro-chondrocytic phenotypes and serves to transmit loads exerted on the spine. As a result of aging or degeneration, the normal extracellular matrix (ECM) turnover may be disturbed; if proteoglycan concentration decreases, disc hydration and disc height are diminished, increasing the strain on the fibres in the AF. This can lead to tears and fissures in the AF and ultimately to protrusion of the NP. On the other hand, injurious mechanical forces in combination with traumatic or degenerative failure of the AF may provoke herniation of disc tissue. Irrespective of aetiology, back pain may occur due to disc protrusions, whether they do or do not enter the spinal canal and exert pressure on the lumbar nerve roots. It is believed that the pain associated with lumbar disc herniation results from a combination of nerve root ischemia and inflammatory processes occurring at the site of extrusion (Takahashi et al., 2008).

Surgical intervention has widely shown positive outcome in cases where conservative treatment including physical therapy, pain medication and epidural steroid injections are not successful. The majority of studies support earlier relief of pain-related symptoms and conceivably superior restoration of function in patients who undergo surgery (Guilfoyle et al., 2007; Spengler et al., 1990; Weber, 1983; Weinstein et al., 2006b; Weinstein et al., 2008). In fact, lumbar disc herniation is the pathological condition for which spinal surgery is most often performed. The incidence of disc surgery is $160 / 100,000$ inhabitants in the USA and $62 / 100,000$ 
in Switzerland, indicating large geographic variations (Andersson and Deyo, 1996; Berney et al., 1990; Weinstein et al., 2006a).

Lumbar discectomy is the most common surgical procedure performed for patients suffering from back pain and sciatica, with over 300,000 operations done yearly in the USA (Atlas et al., 1996; Deyo and Weinstein, 2001). While standard discectomy provides favourable results in the majority of the cases, conditions with unmet needs in terms of treatment include large disc protrusion with only minimal disc degeneration and adolescent disc protrusion. In both conditions, the partial removal of the protruding herniation tissue is indicated, and the breach in the annulus removes the safe constraints encasing and maintaining pressurisation of the gel-like nucleus pulposus. In these cases, recurrent herniations are quite frequent, necessitating revision surgery (McGirt et al., 2009; Lebow et al., 2011). Furthermore, an average disc height loss of $25 \%$ has been reported after discectomy, which has been associated with increased back pain and disability (Barth et al., 2008; Yorimitsu et al., 2001; Loupasis et al., 1999).

Another problem after discectomy is the so-called 'post-discectomy syndrome' involving recurrent herniation with return of symptoms, motivating surgeons to remove a greater portion of disc tissues during the original herniation procedure. A recent investigation suggests that the main source for chronic low back pain after surgical discectomy is discogenic and that annular fissures may be the primary cause for the painful symptoms (DePalma et al., 2012). This finding indicates the need for repairing annular fissures after discectomy.

To prevent recurrent symptoms, novel strategies towards annular repair are compulsory. Efficient AF repair could significantly improve the presently limited surgical outcome, with the largest improvement likely to occur in cases of contained disc herniations but otherwise minor degenerative changes, which mainly occur in relatively young patients. With interdisciplinary collaborations, we are evaluating innovative and clinically relevant approaches to treat AF ruptures, focusing on improving cell-biomaterial interaction for application in disc herniation. Ideally, such a biological construct will, upon implantation, provide immediate closure of the defect and maintain the mechanical properties of the disc, while the cellular component will start the regenerative process.

This article reviews the clinical problems, current treatment options and needs, cellular and biomechanical considerations, and biomaterials required for $\mathrm{AF}$ repair. Furthermore, in vitro and in vivo preclinical models commonly used to test newly developed cell- or materialsbased therapies are outlined. The ultimate goal of our research is to offer the surgeon an off-the-shelf biological solution for treating disc herniations with a single intervention.

\section{Clinical Challenge}

\section{Clinical pathology of the AF}

As an integral part of the functional spine unit (FSU), the annulus fibrosus is involved in almost any pathological condition of the degenerating spine. There are two specific clinical situations for which the impaired function of the AF plays a crucial role: as the source of discogenic low back pain (LBP) and, in the case of insufficiency, as the origin of disc herniation. Both conditions are very common and have an enormous socio-economic impact with no established satisfactory treatment options to date (Gore et al., 2012; Mehra et al., 2012; Parker et al., 2010; Weinstein et al., 2006a; Weber, 1994).

Discogenic low back pain is believed to arise from acute tears or fissures of the AF and from focal defects of the outer AF. These defects result in a repair process where granulation tissue is formed along with neovascularisation and concomitant ingrowth of nerve fibres (Melrose et al., 2002; Freemont et al., 1997; Aoki et al., 2006). Although the AF has not fully lost its main function to withstand the hydrostatic pressure from the NP and to stabilise the FSU, discogenic low back pain has a high likelihood to develop chronicity and often needs medical treatment.

Acute and chronic disc herniations not only generate local pain from the disc but can also create pain and loss of function of the segmental nerves by direct compression and irritation from local inflammatory processes. As this condition has a lifetime prevalence of 1-3\% and often affects active, working persons of 30-50 years of age, the socioeconomic impact due to medical treatment and longterm absence from work are enormous (Weinstein et al., 2006a; Weber, 1994).

\section{Diagnostics and classification}

In the case of disc herniation, a correct diagnosis is usually made due to the irritation of the segmental nerves, which is frequently accompanied by low back pain observed during a clinical examination. The clinical symptoms of discogenic low back pain on the other hand are less specific, which requires a diagnosis that is mostly based on imaging methods and diagnostic infiltrations. Although some typical findings may be present on plain radiographs and computer tomograms, magnetic resonance imaging (MRI) and discography are more sensitive and specific. High intensity zones (HIZ) are believed to be the radiological correlate of the innervated granulation tissue described above; HIZ are found in the outer layers of the posterior AF, mostly radially oriented and show a high prevalence in patients with acute LBP (Kang et al., 2009). However, a large proportion of asymptomatic individuals present HIZ in MRI (among various other abnormalities) (Jensen et al., 1994a; Stadnik et al., 1998; Carrino et al., 2009; Cheung et al., 2009) and therefore confirmation of the diagnosis is performed by provocative discography. Discography has the advantage of better visualisation of the annular defect morphology and provoking a typical pain pattern when increasing the intradiscal pressure (Carragee and Alamin, 2001). As a consequence of recent investigations that have demonstrated the risk of accelerated disc degeneration after discography, the use of this invasive method is currently more restricted and control-discographies of adjacent, healthy, segments are becoming obsolete (Carragee et al., 2009).

For the detection of location and severity of disc herniations and annular tears, MRI is without doubt the 


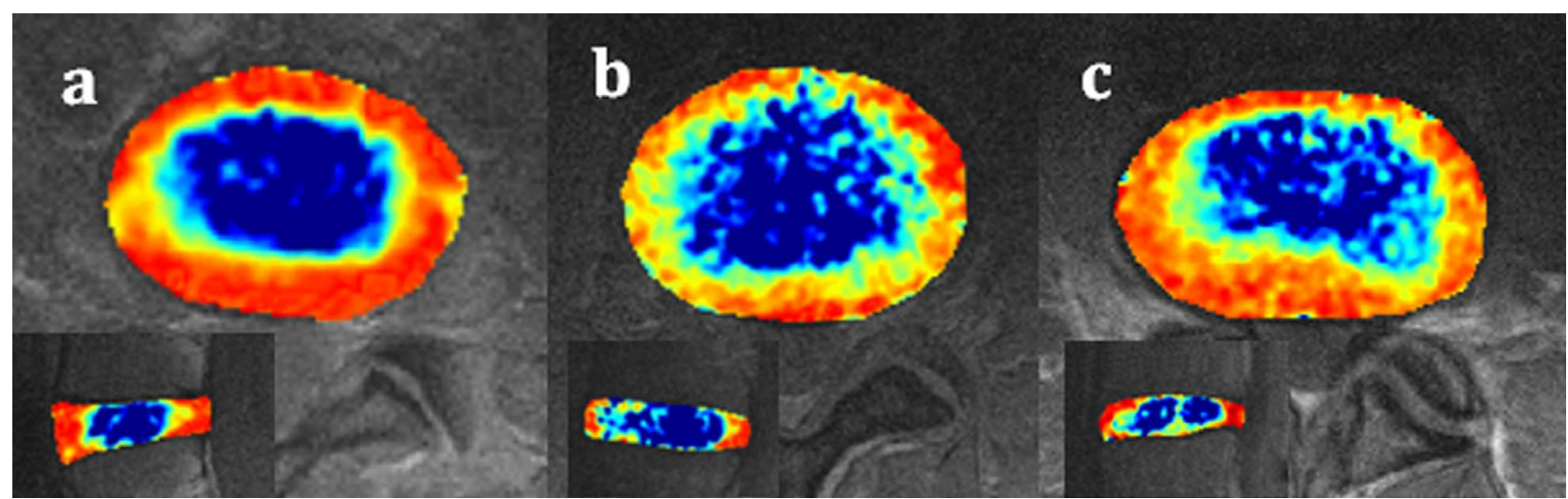

Fig. 1. Axial and mid-sagittal T2-mappings of L4/5 intervertebral discs. a) Healthy disc (grade 1) with clear demarcation of NP/inner/outer annulus; the annulus shows a uniform thickness. b) Moderately degenerated disc (grade 2); demarcation becomes unclear, loss of orientation of annulus fibres, uniform thinning of the AF. c) Moderately degenerated disc (grade 2) with unilateral, posterior thinning of the AF and relatively healthy contralateral AF (Watanabe et al., 2007).

method of choice, as all relevant structures are visible with one non-invasive investigation. There are various classifications of disc herniations, mostly based on their location (central, paramedial, posterolateral, lateral; foraminal or extraforaminal) or degree of protrusion (normal, bulge, extrusion, protrusion, sequestration) (Jensen et al., 1994b). The type of annular tear is usually classified based on sagittal MR images by orientation and localisation of the lesion (concentric, transverse and radial) (Yu et al., 1988). With regards to annulus repair strategies, it is obvious that transverse tears (rim lesions), which represent a disruption of the annulus from the underlying bone, will need a different implant design from the more common radial tears, which are a rupture within the AF itself. The Dallas discogram classification describes the extensions of radial tears within the AF (Sachs et al., 1987). A more complete classification from Carragee et al. (2003) combines the type/extent of herniation and the extent/size of the underlying radial tear and is, therefore, also superior in terms of prognostic value.

Unfortunately, all current classifications focus more on the amount and localisation of herniated NP material and less on the underlying morphology and grade of degeneration of the AF, which would provide essential knowledge in creating a successful AF repair. Modern, quantitative MRI techniques on high field units show a variety of different AF morphologies and have the capability to detect degenerative changes at earlier stages (Watanabe et al., 2007; Hoppe et al., 2012; Zobel et al., 2012). Such individual differences need to be considered in AF repair strategies (Fig. 1).

\section{Current treatment options}

There are several options available today for the treatment of discogenic low back pain. Segmental fusion or prosthetic replacement of the painful disc are established and present satisfactory short-term results for restrictive indication. However, these techniques are invasive, costly and have the potential to generate new problems when the biomechanical properties of the spine are altered, creating potential adverse effects on the adjacent levels (Ekman et al., 2009). Less invasive methods were developed with the intention to denervate the observed pathological ingrowth of nerve fibres into the dorsal AF by thermocoagulation. Techniques like PIRFT (percutaneous intradiscal radiofrequency thermocoagulation) or IDET (intradiscal electrothermal therapy) are still performed, although there is only low quality evidence regarding effectiveness and possible complications such as radiculopathy and infection (Ercelen et al., 2003; Freeman et al., 2005; Kvarstein et al., 2009; Pauza et al., 2004). A less destructive, regenerative treatment is in clear clinical demand, though such a therapy would also have to address the problem of pathological innervation.

Discectomy has been shown to be an effective treatment for acute disc herniation with regard to neurological symptoms, but fails to address the altered biomechanical properties of the segment and the resulting annular defect. In this situation, the surgeon faces the dilemma of how extensive a discectomy should be performed. If only the extruding material of the NP is resected, a relevant risk of recurrent disc herniation is well documented. However, if all or most of the NP is resected, there is also a significant chance that lost biomechanical function leads to instability or collapse of the segment (Moore et al., 1994a; Kambin et al., 1995; Yorimitsu et al., 2001; Suk et al., 2001; Vucetic et al., 1997). NP replacement or regeneration to restore the biomechanical function of the disc as a shock absorber will only be successful in the presence of a functional AF to withstand the necessary intradiscal pressure (Veres et al., 2008; Thompson et al., 2000; Fazzalari et al., 2001). Several attempts to close an AF defect after discectomy have been undertaken, of which the most obvious method of direct suture of the AF is technically very demanding - due to limited space and potential injury to the proximal neurological structures. To our knowledge no clinical studies have been reported, and in animal models no sufficient reinforcement could be shown after experimental AF defects were sutured without the use of sealants such as fibrin glue (Ahlgren et al., 
2000; Heuer et al., 2008b). Despite this, all-inside sutures with anchors that allow this type of minimally invasive application in human patients are already commercially available. In addition, although early promising shortterm results have been presented at scientific meetings, there are still no peer-reviewed publications available that would demonstrate safety and effectiveness of these sutures over a longer period (Bourgeault et al., 2007; Bailey et al., 2010; Guyot and Griffith, 2010). Disc herniations that result from larger radial tears $(>3 \mathrm{~mm})$ with more damage to the inner annulus have a higher risk for recurrence and limited healing potential. For these types of defects, an obvious approach is to introduce an implant that seals and reinforces the $\mathrm{AF}$ defect by either suturing to the remaining $\mathrm{AF}$ (e.g. InClose ${ }^{\circledR}$ ) or anchoring into the adjacent vertebral bone (e.g. Barricaid ${ }^{\circledR}$ ) (Carragee et al., 2003; Osti et al., 1990). Again, despite early promising reports at scientific meetings, there is still a lack of published data that would confirm its safety and efficacy (Bajanes et al., 2007; Ledic et al., 2007). The difficulties in proof of efficacy for AF repair and recent reports of implant dislocation or occurrence of hernias on the contralateral side imply that purely mechanical repair may not be sufficient for all kinds of defects and that biology and morphology of the AF need to be respected (Maestretti et al., 2012).

\section{Biomechanical Demands for AF Repair}

\section{Native AF mechanical properties}

The design of successful AF repair strategies requires a clear understanding of the functional biomechanics of the healthy and diseased disc. The structural and mechanical properties of the healthy disc change from the AF to the NP. The NP is highly pressurised and the AF prevents radial disc bulge by generating large hoop stresses. The annulus also resists large tensile and compressive strains as the disc undergoes 6 degree of freedom motion. The cartilaginous endplate is an interface tissue connecting the disc to the adjacent vertebral bodies, and functions to distribute stresses between the disc and vertebrae and to act as a gateway for nutritional transport in the avascular disc. Therefore, AF repair strategies need to withstand the high tensile hoop stresses generated from NP pressurisation and tensile and compressive stresses resulting from spinal motion.

\section{Changes in the IVD and AF structure in degeneration and disease}

\section{Natural AF aging}

During aging, there is a loss of NP pressurisation, which shifts the load carriage mechanisms in AF and NP regions. ECM breakdown is slow, and degenerative changes accumulate chronically as opposed to an instantaneous or acute insult. Although alterations in the AF may occur later or with less severity than those in the NP during aging, they are very significant and loss of AF integrity may greatly accelerate the rate of degeneration. The range of mechanical properties in the healthy and degenerative disc can be found in Table 1. In general, there is an increase in the compressive modulus due to tissue compaction, a moderate increase in the shear modulus, and an increase in radial permeability (Iatridis et al., 2006). With aging, the width of the annulus is found to increase by $80 \%$, with compressive peak stresses increasing by $160 \%$ (Adams et al., 1996). In addition, there is an alteration to the crosslinking of the fibres (Roughley, 2004), gradual decrease in the number of lamellae and a loss of organisation in these layers, which leads to higher localised shear strains (Iatridis and ap Gwynn, 2004) and a greater opportunity for discontinuities in fibre arrays and cleft formation (Schollum et al., 2010).

\section{Accelerated degeneration or disease}

The age-related changes described previously hold true for the diseased state and many of the processes of aging and degeneration occur in parallel. Abnormal loading not only affects tissue wear but also fluid flow and disc nutrition. Certain areas of the disc, such as the posterolateral region, are subjected to greater stresses and are more susceptible to micro-failure or herniation.

Acute injuries caused by overloading or a remodelling of the disc as a result of altered loading, such as immobilisation, can both result in a degenerative cascade and disease progression (Iatridis et al., 2006). Therefore there exists a healthy window for loading, where too little loading (immobilisation) or too much loading (overloading) can both lead to remodelling with abnormal disc composition, structure and mechanical properties (Stokes and Iatridis, 2004). Acute annular injuries observed in puncture models affect not only the fibre structure but also the pressurisation and fluid flow (Hsieh et al., 2009; Michalek and Iatridis, 2012). While the laminated fibre network in the healthy annulus is highly effective at arresting crack propagation, multiple failure patterns occur with fibre breaks being a likely failure mode, resulting from extreme or abnormal loading conditions (and/or when the collagen network is degraded), whereas delaminations are likely a result of damage accumulation due to annular shearing and loss of NP pressurisation (Iatridis and ap Gwynn, 2004).

Lifestyles exposing people to heavy physical work or vibrations can lead to higher incidences of disc degeneration (Pope et al., 1998; Williams and Sambrook, 2011). However, epidemiological studies have also shown that these lifestyle exposures could play less of a role than genetic influences (Battie and Videman, 2006). It is likely that genetic influences interact with biomechanics and other environmental factors, for example by diminishing AF or NP tissue quality, or through alterations in anthropometric factors, spine shape or muscle attachments that also modify the stress state in the disc (Williams and Sambrook, 2011).

Motion segment dysfunction associated with IVD degeneration

Changes to the spinal motion segment during degeneration begin with a period of hypermobility, which leads to increased tissue stiffness and consequently results in hypomobility. Fujiwara and co-workers observed this with increasing segmental motion through degeneration grade IV, but decreased motion with grade V (Fujiwara et al., 2000). The IVD must withstand large amounts 
Table 1. Biomechanical demands for an AF repair: healthy and degenerative properties of the human lumbar disc.

\begin{tabular}{|c|c|c|c|c|}
\hline & Property & Disc Grade & Property Range & Reference \\
\hline \multirow{6}{*}{ 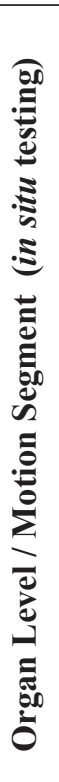 } & \multirow[t]{2}{*}{ Disc height } & Healthy & $11.1 \pm 2.5 \mathrm{~mm}$ & (Chen and Wei, 2009) \\
\hline & & Degenerative & $\begin{array}{l}11.3 \pm 0.3 \mathrm{~mm} \\
9.2 \pm 2.9 \mathrm{~mm} \text { (spondylo-listhetic disc } \\
\text { height) }\end{array}$ & $\begin{array}{l}\text { (O'Connell et al., 2007) } \\
\text { (Chen and Wei, 2009) }\end{array}$ \\
\hline & \multirow[t]{2}{*}{ Intradiscal pressure } & Healthy & $\begin{array}{l}0.5 \mathrm{MPa} \text { (leakage pressure) } \\
1.9 \mathrm{MPa}(300 \mathrm{~N} \text { load pressure) } \\
\text { Single patient } 0.1-2.3 \mathrm{MPa}\end{array}$ & $\begin{array}{l}\text { (Panjabi et al., 1988) } \\
\text { (Adams et al., 1996) } \\
\text { (Wilke et al., 1999) }\end{array}$ \\
\hline & & Degenerative & $\begin{array}{l}0.2 \mathrm{MPa} \text { (leakage pressure) } \\
1.3 \mathrm{MPa}(300 \mathrm{~N} \text { load pressure) }\end{array}$ & $\begin{array}{l}\text { (Panjabi et al., 1988) } \\
\text { (Adams et al., 1996) }\end{array}$ \\
\hline & \multirow[t]{2}{*}{ Torsional mechanics } & Healthy & $\begin{array}{l}0.7^{\circ}-0.8^{\circ}\left(\text { with } 8^{\circ} \text { pelvic rotation }\right) \\
3^{\circ} \max \text { axial rotation } \\
3.18 \pm 0.89 \mathrm{~N} \cdot \mathrm{m} /{ }^{\circ}\end{array}$ & $\begin{array}{l}\text { (Blankenbaker } \text { et al., 2006) } \\
\text { (Haughton } \text { et al., 2002) } \\
\text { (Costi et al., 2007) } \\
\text { (Showalter } \text { et al., 2012) }\end{array}$ \\
\hline & & Degenerative & $1.8^{\circ}-3.2^{\circ}$ (with $8^{\circ}$ pelvic rotation) & $\begin{array}{l}\text { (Blankenbaker } \text { et al., 2006) } \\
\text { (Haughton et al., 2002) }\end{array}$ \\
\hline \multirow{6}{*}{ 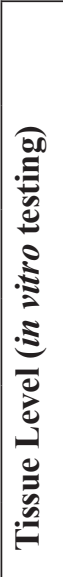 } & \multirow{2}{*}{$\begin{array}{l}\text { Compressive } \\
\text { (confined } \\
\text { compression) }\end{array}$} & Healthy & $\begin{array}{l}0.56 \pm 0.21 \mathrm{MPa} \\
\left(\mathrm{H}_{\mathrm{A}}, \text { aggregate modulus }\right)\end{array}$ & (Iatridis et al., 1998) \\
\hline & & Degenerative & $\begin{array}{l}1.10 \pm 0.53 \mathrm{MPa} \\
\left(\mathrm{H}_{\mathrm{A}}, \text { aggregate modulus }\right)\end{array}$ & (Iatridis et al., 1998) \\
\hline & \multirow{2}{*}{$\begin{array}{l}\text { Tensile } \\
\text { (circumferential } \\
\text { samples) }\end{array}$} & Healthy & 12.7 MPa (E, tensile modulus) & (Acaroglu et al., 1995) \\
\hline & & Degenerative & 9.4 MPa (E, tensile modulus) & (Acaroglu et al., 1995) \\
\hline & \multirow[t]{2}{*}{ Shear } & Healthy & $25<\mathrm{G}_{\mathrm{eq}}(\mathrm{kPa})<110$ & (Iatridis et al., 1999) \\
\hline & & Degenerative & $25<\mathrm{G}_{\mathrm{eq}}(\mathrm{kPa})<140$ & (Iatridis et al., 1999) \\
\hline
\end{tabular}

of compression, measured to be more than $200 \%$ body weight on the lumbar disc during sitting and standing at a $20^{\circ}$ angle (Nachemson, 1966). A successful AF repair would reduce excessive spinal motions, recover nonlinear stiffness behaviours of the motion segment and restore NP pressurisation. Such repair has the potential to inhibit progression of biomechanical alterations in the disc, including tissue compaction, stiffening and pathological remodelling from altered mechanobiology.

\section{Biomechanical Demands for AF Repair}

The repair of a damaged disc is complicated for many reasons, including the risk of reoccurrence as well as the prevention of stress shielding in the tissue, both of which could exacerbate the clinical problem the AF repair strategy is trying to mitigate. From the many mechanical tests that have been performed on AF tissue and described in this review, we parameterise many target tissue and motion segment level biomechanical behaviours. Tissue mechanics remains an important technique for future studies optimising biomaterials by 'tuning' them to match the biomechanical behaviours of native AF tissues. Motion segment mechanics provides another technique required for future studies in order to characterise the capacity of the AF repair to restore biomechanical function of the motion segment.

\section{Finite element models}

While tissue-scale testing can provide target properties for AF repair materials and organ-scale experiments give basic insight into the mechanical response of the disc, they are limited for the study of the internal mechanics of an annular defect and the performance of a repair. Finite element (FE) modelling can provide a more precise description of the local mechanical environment that exists within the damaged tissue and can quantify the mechanical design constraints required for successful AF repair.

The response of the disc to complex loading, and the critical loading cases that determine the risk of prolapse, have been the subject of several simulation studies. ShiraziAdl (Shirazi-Adl, 1989) provided an early estimate of failure limits of the annulus, showing that asymmetric lifting with bending and rotation produces annulus fibre strains over $20 \%$. Fibre rupture initiated in the inner 
posterolateral annulus and propagated as a radial tear. Disc degeneration also influenced the risk of prolapse in an advanced model incorporating the spatial variation in annulus fibre orientation (Schmidt et al., 2007). These studies present a consistent conclusion that complex loading (i.e., combined flexion plus compression, or torsion plus bending) leads to high fibre strains, especially in the posterolateral annulus (Wang and Li, 2005).

The process of creating and validating a numerical simulation itself can provide valuable insight into the micro- and macro-mechanical response of the annulus. Complex loading of disc specimens, following a stepwise reduction of the structure (posterior elements and ligament transection, anterior and posterior longitudinal ligament transection, nucleotomy) (Heuer et al., 2008a), has shown the important dependence of the annulus on the nucleus for internal support. These data were incorporated into the validation of the intrinsic material properties of the annulus in simulation models (Schmidt et al., 2006), where only one unique combination of ground substance and fibre properties was valid for all loading directions and magnitudes, which provides a potential design target for AF repair materials. In a bottom-up approach, starting with known individual fibre properties (Malandrino et al., 2012), the predicted optimal region-specific fibre orientation for normal annulus function is consistent with previous anatomical and biomechanical descriptions (Schmidt et al., 2007).

A thorough understanding of the mechanical consequences of annular lesions is critical for the development of repair strategies. Surprisingly little information is available. The effects of radial and circumferential lesions have been analysed in a non-linear segmental model where injury was modelled by element removal in the posterolateral portion of the disc (Goel et al., 1995). Interlaminar shear stresses were higher in the posterolateral regions of intact discs under compression and increased with annular injury. Furthermore, stresses and disc bulge were also sensitive to circumferential injuries. The effects of rim, radial or circumferential annular lesions were investigated, with or without the simultaneous loss of nuclear pressurisation (Little et al., 2007). Loss of nucleus pulposus pressure had a greater effect on the disc mechanics than the presence of annular lesions, implying that the development of annular lesions alone (prior to degeneration of the nucleus) had minimal effects on disc mechanics. However, nucleus depressurisation likely leads to an inward bulge of the annulus, consistent with in vitro findings (Heuer et al., 2008a) and accelerates annulus damage, thus restoration of the nucleus should be considered a parallel design goal of AF repair.

Simulation tools to assess functional performance of AF repair strategies are rare. While suturing techniques for AF repair have been proposed for decades, simulation of the retention of intradiscal pressure following annular suturing has only recently been reported (Chiang et al., 2012). In a segmental model, a modified purse string suture technique was compared to two simple horizontal sutures or a single continuous crossed suture. Closure of a $4.8 \mathrm{~mm}$ transverse cleft was simulated and the modified suturing technique showed a substantially higher sealing potential.
This was validated in a subsequent in vitro trial, where higher nuclear pressures could be retained under load. The only other reported simulation of AF repair evaluated the performance of a biomimetic composite disc implant consisting of an artificial polymer nucleus contained within a fibre-reinforced textile annulus (Noailly et al., 2012). Parametric variation of the material properties and fibre orientation was performed with the goal of optimising implant design to match global biomechanical properties of the natural disc. While the material properties were shown to play an important role, fibre orientation was especially relevant for the control of torsional loading (and by association annulus loading). This finding highlights how simulation models offer an important and underutilised tool to rapidly screen repair strategies and advance the design of AF repair methods.

\section{Cells of the AF}

\section{Cell morphology and ECM}

The mechanical function of the AF strongly depends on the structure of the ECM, which is maintained by a sparse population of cells; the average cell density in human AF approximates $9000 / \mathrm{mm}^{3}$ (Maroudas et al., 1975). AF cells are derived from the mesenchyme and have been described as fibroblast-like cells with spindle shaped morphology (Roberts et al., 2006). However, marked regional variations in cell morphology exist that appear to correspond with the local mechanical environment (Bruehlmann et al., 2002). Morphologic and molecular studies also provide evidence for the presence of a distinct cell polarity in the AF cells (Gruber et al., 2007a). Molecules with roles in cell polarisation, e.g. PAR 3, were expressed more abundantly in outer compared to inner AF and to NP cells and may be important for the synthesis of the specialised lamellar structure.

The inter-lamellar septae consist of proteoglycan aggregates with water-binding characteristics similar to those in the NP, whereas the lamellar layers contain monomeric proteoglycan molecules that interact with collagen fibres (Ortolani et al., 1988). The microfibrillar network is suggested to play a crucial mechanical role (Yu et al., 2007). Without distinguishing regional variations, the glycosaminoglycan (GAG) to hydroxyproline ratio within the AF of human lumbar discs was found to be on average 1.6:1, with little variations among age or degeneration levels (Mwale et al., 2004). This is in contrast to the NP, where a GAG to hydroxyproline ratio of approximately 25:1 was found in young healthy discs, while this ratio was decreased to about 5:1 in degenerative NP.

\section{Cellular phenotype}

Expression ratios of matrix proteins have also been considered to distinguish between cellular phenotypes in $\mathrm{NP}, \mathrm{AF}$ and articular cartilage (AC). While both COL2/ $\mathrm{ACAN}$ and COL2/COL1 ratios were highest in $\mathrm{AC}$, COL2/ACAN was higher in AF than NP and COL2/COL1 higher in NP than AF cells (Clouet et al., 2009). This study with rabbit cells also found significantly increased expression of collagen type $\mathrm{V}$ in $\mathrm{AF}$ compared to both 
Table 2. Selection of matrix and phenotypical characteristics of the annulus fibrosus.

\begin{tabular}{|l|l|l|l|}
\hline \multicolumn{1}{|c|}{ Marker molecule } & \multicolumn{1}{|c|}{$\begin{array}{c}\text { Characterisitc } \\
\text { (Method used) }\end{array}$} & \multicolumn{1}{|c|}{ Species } & \multicolumn{1}{|c|}{ Reference } \\
\hline Glycosaminoglycan / Hydroxyproline ratio & Ratio 1.6:1 (biochemical assay) & Human & (Mwale et al., 2004) \\
\hline Elastin & $\begin{array}{l}\text { Co-localisation with fibrillin-1 } \\
\text { (immunohistochemistry) }\end{array}$ & $\begin{array}{l}\text { Human; } \\
\text { bovine }\end{array}$ & (Yu et al., 2007) \\
\hline Decorin, Lumican & $\begin{array}{l}\text { Decreased in aged ( }>70 \text { y) AF } \\
\text { (Western Blot) }\end{array}$ & Human & (Singh et al., 2009) \\
\hline Collagen II / Collagen I ratio & AF<NP<AC (RT-PCR) & Rabbit & (Clouet et al., 2009) \\
\hline Collagen V & AF>NP=AC (RT-PCR) & Rabbit & (Clouet et al., 2009) \\
\hline $\begin{array}{l}\text { Collagen I; Collagen III; Collagen V; } \\
\text { Cadherin-13; Decorin; Versican v3 }\end{array}$ & NP/AF $<0.1$ (Microarray) & Rat & (Lee et al., 2007) \\
\hline $\begin{array}{l}\text { Laminin B1; Collagen I; Collagen XIV; } \\
\text { Aquaporin 1; CD 163; Caveolin 3; } \\
\text { Haemoglobin beta }\end{array}$ & NP<AF (Microarray) & Canine & (Sakai et al., 2009) \\
\hline $\begin{array}{l}\text { Tenomodulin; TNFAIP6; FOXF1; FOXF2; } \\
\text { Aquaporin 1 }\end{array}$ & $\begin{array}{l}\text { AF>NP and AC (Microarray, } \\
\text { RT-PCR) }\end{array}$ & Bovine & (Minogue et al., 2010) \\
\hline
\end{tabular}

NP and AC cells, suggesting that type V collagen could potentially be used as a phenotypic marker for AF cells. To explore the phenotypic characteristics of IVD cells more comprehensively, microarray analyses were performed comparing IVD with the phenotypically similar AC cells. Although often greater emphasis was put on the expression profiles of NP cells, these studies are also relevant for AF cells. In rat cells, 10 genes with NP/AF intensity ratios $\leq 0.1$ were found, including the proteoglycan decorin (Lee et al., 2007). In a similar investigation on beagle dogs, 77 genes with a NP/AF signal $\log$ ratio of -1 or lower were identified, including collagen XIV, cell adhesion molecules and integrin precursors (Sakai et al., 2009). Tenomodulin, a member of the small proteoglycan family, was proposed as a marker for the AF cell phenotype, being expressed at higher levels in AF compared to NP and AC cells in both bovine and human species (Minogue et al., 2010). However, inter-species variations have generally been observed, and difficulties to detect clear differences between AF and NP cells have often resulted in the general classification of a gene as marker for the IVD phenotype (Rutges et al., 2010; Minogue et al., 2010; Power et al., 2011). Table 2 summarises some characteristics of the cellular phenotype and the extracellular matrix of the AF that are known to date. Further research will be necessary to more precisely define the AF cell, since the maintenance or acquisition of the correct cell type is a crucial requirement for successful cell therapy. This is particularly important for differentiation of therapeutic MSCs towards the AF cell phenotype.

\section{Phenotype changes during degeneration}

During IVD degeneration, changes in levels of proteoglycans can be observed (Cs-Szabo et al., 2002; Singh et al., 2009). Especially, AF cells may respond to early degeneration by increasing biosynthetic processes, while in severely degenerated tissue a decline in aggrecan and increases in concentrations of small proteoglycans, such as decorin, biglycan and fibromodulin, may account for the failure of effective repair. Furthermore, tenomodulin expression was found to be increased in degenerative human AF cells (Minogue et al., 2010). Other correlations between the expression of certain genes and age or degeneration state were identified, such as an increase in pleiotrophin mRNA in AF cells with increasing patient age (Rutges et al., 2010), which might be related to an increased vascular ingrowth in degenerate AF (Johnson et al., 2007). Higher levels of glypican-3, cytokeratin-19, matrix gla protein and pleiotrophin were also found in aged compared to young tissue in the rat (Lee et al., 2007).

In order to investigate changes in gene expression profiles of AF cells during degeneration, genome-wide microarray analyses were performed. Laser capture microdissection was used to harvest cells from paraffinembedded sections of human AF tissue from different degeneration grades (Gruber et al., 2007b). Genes significantly altered during degeneration included cell senescence, cell division, hypoxia-related and other genes important for cell survival. Similarly, in AF cells cultured in 3D carriers, differences in gene expression patterns between healthier and more degenerative discs were observed for a variety of molecules involved in AF metabolism (Gruber et al., 2010). Important genes included those related to ECM synthesis or degradation, cell proliferation, apoptosis, growth and differentiation, or inflammation. Further data also showed that gene expression patterns related to mitochondrial dysfunction were present in the human AF from more degenerative discs (Gruber et al., 2011). In particular, changes were identified in genes involving apoptosis, oxidative stress and senescence.

\section{Cell nutrition}

Given that blood supply is restricted to the borders of the cartilaginous endplate and the AF, the two possible ways for nutrient transport are the endplate and the peri-annular 
route. For the latter, the amount of nutrients transported depends on the transport properties and the cellular metabolic rates of the tissue. The diffusion of nutrients through the AF may depend on the strain and the direction of diffusion, i.e. the anisotropy of the tissue (Jackson et al., 2008). There are marked gradients in oxygen concentration across the avascular disc, dropping to as low as $1 \% \mathrm{O}_{2}$ in the centre of a large disc (Urban et al., 2004). While low oxygen is known to promote the NP cell phenotype, AF cell phenotype and metabolic activity do not seem to be affected by changes in $\mathrm{O}_{2}$ levels (Mwale et al., 2011). Nonetheless, organ cultures have shown that impaired glucose supply can be detrimental for the survival of both NP and AF cells (Junger et al., 2009; Illien-Junger et al., 2010).

\section{Regenerative potential}

Although the IVD is considered to have a poor intrinsic repair capacity, minor self-repair processes have been observed, especially in the outer AF (Melrose et al., 2007). Chemotactic mechanisms may play a role in AF repair, as AF cells can be recruited by chemokines, and chemokine receptors have been identified on human AF cells (Hegewald et al., 2012). Recent studies have confirmed continuous cell proliferation in different parts of the IVD, though the proliferation rate is suggested to be low (Henriksson et al., 2009). Findings of distinct stem/ progenitor cell niches in the AF border to ligament zone and the perichondrium region also suggest that these cells may be recruited to migrate into the disc (Henriksson et al., 2009), where they may act together with local progenitor cells and potentially with bone marrow-derived mesenchymal stem cells (MSCs) to maintain regenerative processes. Potential migration routes from these stem cell niches towards the AF and the inner parts of the disc have recently been reported (Henriksson et al., 2012). There is also increasing evidence that progenitor cells with characteristics of MSCs are present in the NP, the AF, and the cartilaginous endplate of healthy and degenerated human adult discs (Risbud et al., 2007; Blanco et al., 2010; Feng et al., 2010; Liu et al., 2011). This intrinsic repair capacity might not be sufficient or might be disturbed by inflammatory and catabolic processes that accelerate matrix degradation (Wuertz et al., 2012). Therapeutic approaches have therefore addressed both the repopulation of the disc with autologous cells and supplementation of anabolic, anti-catabolic or anti-inflammatory agents. For AF repair, autologous AF cells could potentially be obtained from a surgical sample and used for regenerative therapy with or without a suitable biomaterial scaffold. However, as such procedures are technically demanding and AF cells from degenerating discs often show signs of senescence, the focus has been directed towards the application of MSCs derived from the bone marrow or potentially from adipose tissue. Although MSC-based IVD regeneration has been well documented, treatments have generally aimed to restore the NP rather than the AF (Grad et al., 2010; Orozco et al., 2011). Co-culture of MSCs and AF cells in vitro indicates stimulatory effects in terms of ECM synthesis (Le Visage et al., 2006), and it can be postulated that both paracrine factors released by MSCs and MSC differentiation may contribute to tissue regeneration. Based on the highly oriented structure and the mechanical function of the AF, the structural and mechanical environment is suggested to be a critical determinant of the cell phenotype that also may guide the differentiation of MSCs (See et al., 2011; Nerurkar et al., 2011a).

In conclusion, further research is needed to identify the optimal cellular environment that supports the AF cell phenotype, whereby inner and outer AF should be distinguished. Moreover, although it is well recognised that apoptosis, senescence and increased synthesis of inflammatory and catabolic mediators play a role in degeneration of the human disc, there is still very little understanding of the underlying causes at the cellular and molecular level. Finally, additional studies are required to characterise the progenitor/stem cell types that reside in the IVD and adjacent tissues and to find ways for in situ mobilisation of these immature cells for tissue repair.

\section{Biomaterials}

An ideal AF biomaterial structure achieves instant and prolonged mechanical stability and allows new competent tissue to form. Current biomaterial-based strategies aimed at the regeneration of AF tissue focus either on developing an implant that restores the mechanical function of the damaged or diseased AF; on preparing a scaffolding architecture that supports AF and other relevant cells; or on delivering biologics where biologically active compounds and cells promote ECM production and new tissue formation.

\section{Biomaterials-mediated delivery of biologics}

The rationale for using biomaterials to deliver biologics is to transport exogenous biological material (cells, proteins, genes, drugs) to a target site where these biomolecules can provide the desired therapeutic effect on the targeted pathology. The AF tissue consists of a variety of cell populations and tissue microstructures that reflect the different physiological stresses experienced. This complicates tailoring a suitable delivery system to the AF (Fig. 2).

\section{Cell delivery}

Cell delivery addresses the problem of increased cell death, senescence and lack of paracrine factors in the degenerative disc. Cells delivered to the degenerative disc are envisaged to repopulate the region where the native cells and ECM have been lost. The transplanted cells deposit new matrix proteins, enabling the disc to recover its function. There have been no in vivo studies that have attempted to deliver cells to the degenerative AF. The cell choice remains a critical issue, given that the application of bone marrowderived MSCs might lead to unwanted bone formation (Vadala et al., 2012), in particular in combination with growth factors. A recent in vitro study investigating the suitability of AF cells, chondrocytes and bone marrowderived cells supplemented with recombinant human bone morphogenetic protein 2 (rhBMP2), concluded that chondrocytes are the best candidates for cell delivery to the disc based on sGAG production, mRNA and protein 

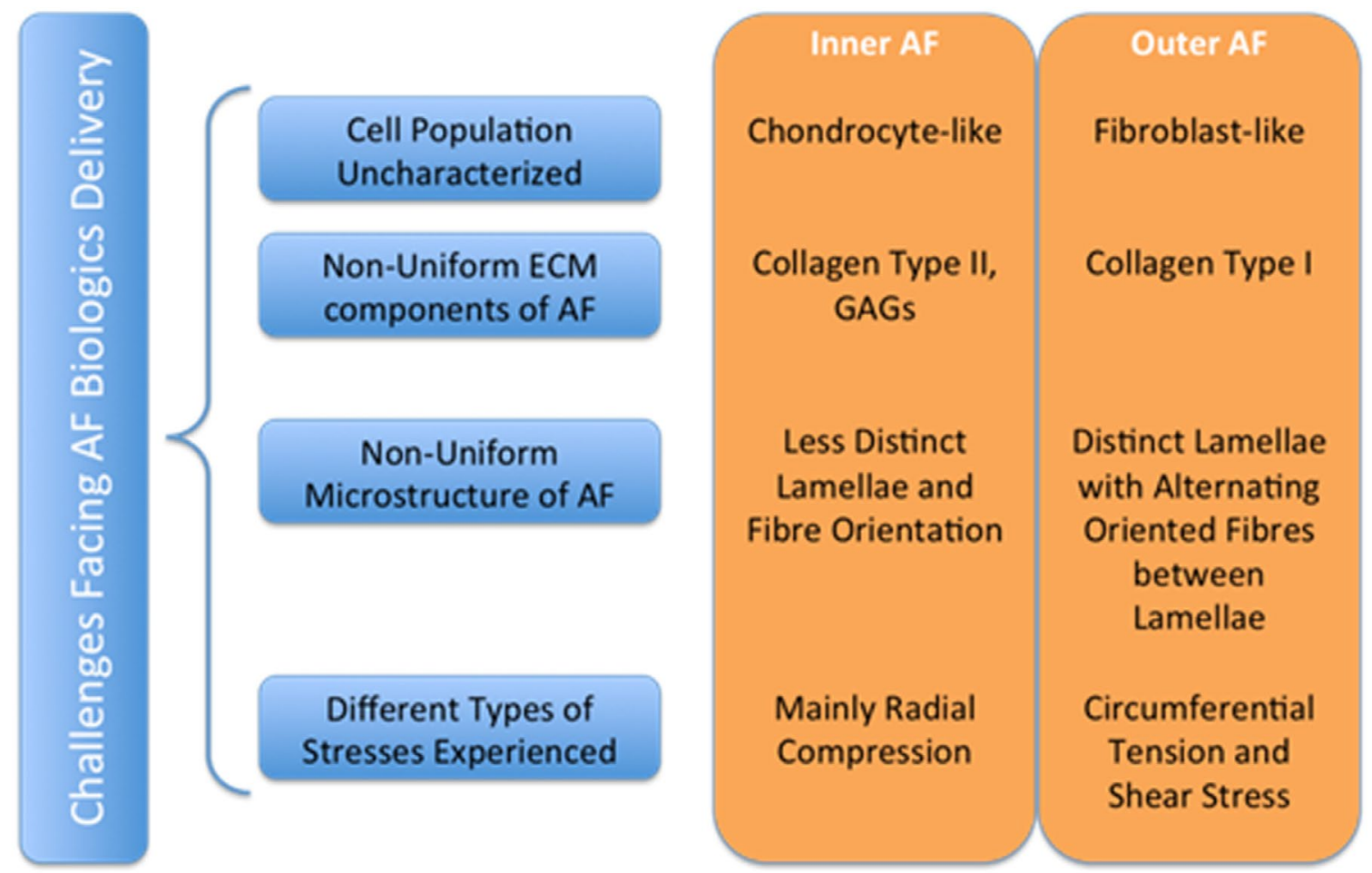

Fig. 2. Schematic of the challenges facing AF biologics delivery.

expression of aggrecan and collagens (Kuh et al., 2009). Yet, as previously discussed, AF cells are currently not well characterised; moreover, the study performed in 2D cell culture limits the relevance of the findings for cell delivery approaches. Significance will increase with the use of appropriate 3D cell delivery vehicles in conjunction with established cell phenotypes (Collin et al., 2011). Ultimately, only longer term organ culture and in vivo studies that also take the clinical applicability into consideration will reveal advantages and limitations of different cell therapies.

\section{Protein delivery}

The delivery of proteins encompasses growth factors, enzymes and cytokines. Ideally, biomaterials-based delivery systems allow for proteins to have a sustained effect on the target system, such that repeated administration of the proteins can be obviated. Despite the number of studies that have reported the delivery of proteins for therapeutic intervention, none have studied the feasibility of using a biomaterial-based platform to deliver proteins to the AF. In fact, the efficacy of these systems could be drastically improved by incorporation in a non-cytotoxic biomaterial tailored to release the protein in a timely and spatially controlled manner. In addition, the biomaterial can protect and maintain the functionality of the protein over the sustained release time period. The development of such delivery vehicles requires deep understanding of the growth factor functions in AF therapy. The only delivery system that has been reported to have a prolonged effect on the cells (up to a few weeks) is viral gene delivery (Gilbertson et al., 2008; Zhang et al., 2007; Zhang et al., 2009).

\section{Gene delivery}

There are two main methods of gene delivery, i.e. virusmediated and non-viral methods. For AF gene therapy, most studies have used adenovirus as the vector. Gilbertson et al. (2008) and Zhang et al. (2007; 2009) both reported the efficacy of various BMPs for ECM production. Virus-mediated gene transfer, delivering growth and differentiation factor-5 (GDF-5) (Liang et al., 2010), and LIM mineralisation protein-1 (LMP-1) (Yoon et al., 2004) were both reported to enhance matrix deposition in in vivo models. Lentiviral shRNA silencing of CHOP (C/EBP homologous protein), an apoptosis regulated gene, was shown to inhibit stretch-induced apoptosis in AF cells. Intradiscal injection of this shRNA improved MRI and histologic scores in a rat model, confirming the potential of anti-apoptotic gene therapy (Zhang et al., 2011d).

However, all viral gene delivery systems have the inherent problem of potentially becoming infectious. Nonviral delivery systems might therefore be the preferred delivery vehicle. The drawback of non-viral gene delivery systems is the low transfection efficiency. Many studies are now investigating more efficient protocols that use naturally occurring ECM components like elastin, chitosan and hyaluronan to aid in delivery of genes (Dash et al., 
2011; Mahor et al., 2011; Rethore et al., 2009). These systems have the flexibility to alter the rate at which exogenous DNA is released to the surrounding cells and also demonstrate an improvement in gene expression. With viral gene delivery systems becoming more unattractive due to the possibility of inherent complications, these newer non-viral controlled gene delivery systems will play an increasing future role in gene therapy for $\mathrm{AF}$ regeneration.

\section{Biomaterial scaffolding and support structures Natural materials and biological considerations}

To create extracellular matrix analogues and provide substitute materials for AF repair (Gruber et al., 2006), tissue-engineering scaffolds have been prepared from natural materials. Investigators have prepared biomimetic matrices based on collagen, a major component of the AF ECM. Collagen is used in the form of gels or as threedimensional porous structures and has several advantageous properties, such as a weak immunogenicity and the ability to support a large variety of cell types (Gruber et al., 2004). In AF tissue regeneration, mainly collagen type II has been used. When compared to collagen type I, which is also abundantly present especially in the outer parts of the AF, scaffolds prepared from collagen type II showed better maintenance of cell numbers and higher production of ECM (Saad and Spector, 2004). These scaffolding structures were also combined with glycosaminoglycans, such as chondroitin-6-sulphate and hyaluronan, to mimic more closely the extracellular matrix composition (Liu et al., 1999; Schneider et al., 1999; Yannas et al., 1989; Alini et al., 2003). Analogous gels have also been prepared from other natural hydrogels, such as alginate (Bron et al., 2011; Chiba et al., 1997; Maldonado and Oegema, Jr., 1992; Wee and Gombotz, 1998), agarose (Gruber et al., 1997; Gruber et al., 2004) and chitosan (Shao and Hunter, 2007). The remarkable mechanical properties of silk, combined with a very high propensity for cell attachment, make it a material of great interest for use in AF tissue engineering (Chang et al., 2007; Chen et al., 2003).

Soluble atelocollagen from collagen type II has been considered for IVD regeneration (Sakai et al., 2003; Sakai et al., 2006; Sato et al., 2003a; Sato et al., 2003b). In this form, compositions containing cells have been investigated for AF tissue regeneration (Alini et al., 2003; Alini et al., 2002; Sakai et al., 2006; Sakai et al., 2003). To create and regulate circumferential fibril alignment, cell-induced contraction of collagen type I gels was achieved using AF cells, and the feasibility of this technique for tissue engineering of entire IVDs was demonstrated in vitro and in a rat model in vivo (Bowles et al., 2010; Bowles et al., 2011). Tissue regenerating compositions that can be injected into the degenerative disc offer advantages over the more invasive surgical approaches required when implanting (cell seeded) scaffolds.

The reported biomaterials and scaffolds adequately support cells, but unfortunately they are until now inherently mechanically weak compared to AF tissue. Thus, research has focused on the necessity to create scaffolds with mechanical properties that better resemble those of the natural AF.

\section{Synthetic materials}

To obtain scaffolding structures with more appropriate mechanical properties than those of most natural materials available, many studies have been conducted on the use of synthetic biodegradable polymeric materials. Synthetic polymeric biomaterials have proven to be useful in many tissue engineering applications, possessing important characteristics such as their highly reproducible syntheses and predictable properties, their lack of immunogenicity and their ease of processing into desired structures and implants (Freed et al., 1994). Poly( $\varepsilon$-caprolactone) (PCL), poly(lactide) (PLA) and poly(glycolide) (PGA) and copolymers prepared from the respective monomers are synthetic polyesters that have been studied for AF tissue regeneration. Mizuno et al. (2006) used a nonwoven mesh of PGA fibres coated with PLA to generate AF scaffolds for construction of composite tissue engineered IVDs. Several of these biodegradable polymers have also been used to prepare composite materials with ceramics (Blaker et al., 2005; Helen et al., 2007; Wilda and Gough, 2006) or with natural polymers such as hyaluronic acid (Choi et al., 2009; Nesti et al., 2008) and fibrin (Moutos et al., 2007; Sha'ban et al., 2008a; Sha'ban et al., 2008b). In this manner, the scientists aimed to enhance integration with tissue and biological activity of the structure. Furthermore, potentially detrimental effects of the polyester degradation products could be counteracted (Coombes et al., 2002; Sherwood et al., 2002).

Polyurethane and polyamide scaffolds presenting polar surfaces might improve cell adhesion and tissue integration (Attia et al., 2011; Santerre et al., 2005; Yang et al., 2009). Also, the visco-elastic properties and flexibilities of these synthetic biodegradable polymers resemble those of the AF without the highly complex architecture of the tissue, which makes them very attractive as biomaterials for AF repair.

\section{Oriented scaffolding structures}

To engineer annulus fibrosus with properties similar to that of native tissue, the design and preparation of scaffolds which recapitulate some of the mechanical features of the complex structural anisotropy of the AF and can induce orientation of newly produced ECM are being investigated (Johnson et al., 2006). Numerous AF scaffolding structures have been prepared using a variety of techniques, which include freeze-drying (Cole et al., 1985; Rong et al., 2002; Sato et al., 2003a; Sato et al., 2003b; Schneider et al., 1999), salt-leaching (Wan et al., 2007; Wan et al., 2008), weaving and non-weaving (Mizuno et al., 2006; Moutos et al., 2007), thermally induced phase separation (TIPS) (Blaker et al., 2005) and electrospinning (Koepsell et al., 2011; Nerurkar et al., 2009; Nesti et al., 2008).

Electrospinning is the most often used method to prepare porous membranous structures for use as AF tissue engineering scaffolds. It allows the preparation of highly porous structures composed of large numbers of fused oriented nanofibres that mimic the oriented collagen fibres in the native AF (Fig. 3). There is in fact a major trend toward the design and preparation of oriented biomaterials.

Nerurkar et al. (2007; 2009; 2010; 2011a; 2011b) demonstrated the potential of electrospinning PCL to 

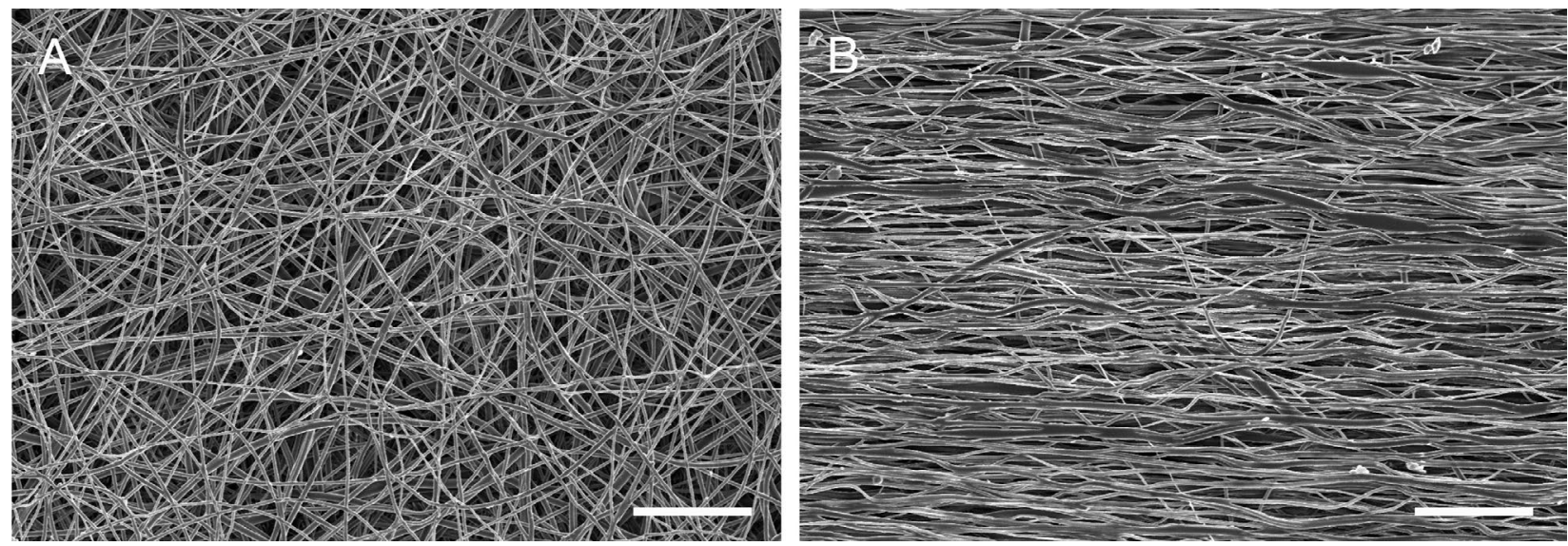

Fig. 3. Scanning electron microscopy images of the surface of non-oriented (A) and oriented (B) electrospun biodegradable segmented poly( $\varepsilon$-caprolactone)-isosorbide poly(ester-urethane) fibrous scaffolds. Scale bar $=20 \mu \mathrm{m}$.

generate AF-like tissue. Their scaffolds were composed of layers of nanofibres oriented at specific angles similar to the native tissue. As the scaffold mimics the anisotropy and non-linearity of AF tissue, it is a most suited substrate for AF cell and/or MSC adhesion and the oriented ECM production that is necessary to obtain the proper mechanical properties. To date, the most promising results in terms of recapitulating AF mechanical properties and directing cell behaviour have been obtained with these anisotropically oriented scaffolds.

The growing interest in IVD repair and AF tissue engineering in recent years has provided fundamental understanding for the rational conception of regenerative biomaterial implants for AF repair. A biomaterial-based regenerative therapy for the damaged or diseased AF has not yet been reported, but this biomaterial will probably allow for new tissue formation and integration with the host via the delivery of biologics. At the same time it will provide the necessary structural and mechanical stability for functional recovery, preventing re-herniation and expulsion of the NP.

\section{Preclinical Models}

There is a general agreement that the ideal model that reflects the degenerative changes occurring in the human IVD does not exist to date. Nevertheless, both in vivo models and organ culture systems have provided an important insight into the feasibility and mechanisms of new treatment methods to repair or regenerate a damaged disc. Every model has its limitations, and these need to be carefully taken into account in the experimental design and the interpretation of study results (Alini et al., 2008). While novel cell- and material-based NP regeneration has been addressed in various investigations, work that has focused on AF repair is fairly limited. This appears surprising, given that an induced IVD disease model often implies an AF defect.

\section{Small animal models}

For basic studies investigating the metabolic and phenotypic responses of endogenous cells or therapeutic cell populations to changes in their environment, small animal models are useful and can provide important fundamental understanding. Genetic modifications such as the use of mice deficient in a distinct structural or regulatory protein have revealed the specific roles of these molecules. For example, it was found that GDF-5 was essential for the normal lamellar architecture of the AF and the structure of the NP (Li et al., 2004), and that a deletion of type IX collagen led to premature onset of IVD degeneration (Boyd et al., 2008). Recently, the DNA repair deficient mouse model of accelerated aging, which had been reported to exhibit age-related IVD degeneration, was used to explore the role of the NFKB signalling pathway in the onset of age-dependent degenerative changes (Nasto et al., 2012).

Mechanical injury models have also been described in mice for proof of concept of gene therapy approaches. Adenoviral delivery of GDF-5 was able to restore the function of a disc in which degeneration had been induced by needle puncture of the AF (Liang et al., 2010). Mechanical intervention has frequently been used to induce degenerative changes also in the rat-tail model. Increased or decreased loading or motion and annular injury have been demonstrated to affect the IVD integrity (Yurube et al., 2012; Zhang et al., 2011a; Wuertz et al., 2009). Furthermore, rat models have been employed to investigate the potential of cell therapy (Wei et al., 2009a) and of gene therapy/gene modulation (Zhang et al., 2011d). While in the latter work gene silencing was proposed to prevent AF cell apoptosis, studies specifically focusing on AF repair are rare. Recently, the feasibility of replacing a native rat caudal IVD by an engineered whole IVD composite was documented (Bowles et al., 2011). The tissue engineered construct could maintain disc height, accumulated newly synthesised matrix, integrated into the spine, and showed dynamic mechanical properties similar to native discs. Nevertheless, the composites lacked the lamellar structure of the AF and the native distribution of collagen types I and II, and major challenges remain regarding the translation of such a concept to larger animals and into clinics.

Rabbits have commonly been used as models for the evaluation of new IVD regenerative therapies. The most widely applied surgical intervention is to injure the 
AF. Total annular puncture causes NP avulsion and the occurrence of disc degeneration within a relatively short time. Therefore, this model has been used to study the effect of injection of growth factors, such as GDF-5 or osteogenic protein 1 (OP-1) (Masuda et al., 2006; Chujo et al., 2006; Kim et al., 2005; Sobajima et al., 2005). In a rabbit nucleotomy model, injection of autologous MSCs embedded in atelocollagen gel not only restored the NP but also the inner AF structure, significantly improving disc height and MRI signal intensity (Sakai et al., 2006). Nevertheless, a critical risk of annular puncture, that should not be underestimated, is the leakage of injected MSCs that may induce serious side effects such as osteophyte formation, finally leading to the formation of mineralised tissue. Such observations highlight the need not only for stable cell carrier materials but also for effective annulus repair technologies (Vadala et al., 2012).

\section{Large animal models}

Larger animal models with disc size, loading and nutrition conditions close to the human are required to assess the efficacy of new procedures or materials for IVD regeneration and in particular for AF repair. The effect of directly repairing three different annular incisions on the healing strength was tested in a sheep model (Ahlgren et al., 2000). When annular defects, followed by partial discectomy, were either repaired directly or left unrepaired to heal spontaneously, no significant differences in the healing strength were noted. In another sheep model an annulotomy was created and repaired by grafting a patch and plug made of small intestinal submucosa (Ledet et al., 2009). Although the treated levels did not maintain the MRI signal intensity of intact levels and the newly formed AF tissue was sparsely organised without specific orientation and lamellar-like structure, the annular closure was improved and resulted in a functional recovery compared to the untreated annulotomy levels.

A number of studies have utilised the ovine annular rim-lesion model since its development in 1990 (Osti et al., 1990). Such superficial lesions are considered clinically relevant, as connections between lesions and radiating tears have been found in aged spines (Vernon-Roberts et al., 2007). Degeneration after a partial AF lesion is slower than after total AF puncture and involves active degenerative processes. Fixation failed to stabilise the affected IVD and could not prevent subsequent degenerative changes (Moore et al., 1994b). Controlled outer AF lesions $5 \mathrm{~mm}$ deep by $5 \mathrm{~mm}$ wide have generally led to (i) early spontaneous repair of outer AF defects, (ii) propagation of inner AF defects, i.e. delamellations, circumferential, radial or transverse tears resulting in severe distortion of the AF structure, loss in disc height and degeneration, and (iii) vascular changes in the endplate and adjacent vertebrae (Melrose et al., 2008). A recent investigation revealed that deregulation of metalloproteinases is involved in the changes ultimately leading to mechanical destabilisation (Melrose et al., 2012). The efficacy of a single injection of rhBMP13 at the site of a controlled annular stab injury in an ovine model was recently demonstrated (Wei et al., 2009b). BMP13 treatment resulted in prevention of cell loss (or cell mobilisation), prevention of neo-vascularisation, deposition of collagen fibres in the AF, production of proteoglycans in the NP, and retention of the original disc height.

A model of annular injury was also described in miniature pigs, where consistent sequential and progressive degeneration was observed that did not improve by the final time point of 39 weeks (Yoon et al., 2008). Furthermore, a porcine annular puncture model was utilised to test the efficacy of non-cell-based materials to prevent the recurrence of disc herniation (Wang et al., 2007). Disc injuries could not be recovered within a 2-months healing period and the implantation of gelfoam material improved the disc integrity.

Goat models of disc degeneration have been described, including annular injuries with a surgical blade or a $4.5 \mathrm{~mm}$ drill bit, whereby the latter resulted in more significant histological changes (Zhang et al., 2011b; 2011c). A reproducible, mild but progressive degeneration of a goat disc can be achieved by injection of a defined concentration $(0.25 \mathrm{U} / \mathrm{mL})$ of chondroitinase ABC (Hoogendoorn et al., 2008). In general, these models have recently been employed to evaluate novel NP regenerative therapies, while reports of AF repair strategies are limited to date.

An attractive approach is the use of specific breeds of dogs that show spontaneous IVD degeneration as a translational model (Bergknut et al., 2012). In chondrodystrophic breeds, signs of degeneration are already observed in young animals ( $<1$ year), while in nonchondrodystrophic breeds only older animals (5-7 years) show degenerative changes. Close similarities in the gross pathology and histology can be observed between humans and dogs. Spontaneous models are more difficult to use for evaluation of therapy approaches, as progression cannot be controlled and large variations between animals, even from the same breed, are expected. Ultimately, all animal models can only answer specific research questions regarding methodology, materials or cellular responses, while the human pathology cannot be reproduced.

\section{Organ culture models}

As a striking alternative to in vivo studies, organ culture models have been developed that enable the maintenance of large animal IVDs with endplates in a controlled ex vivo environment. This approach allows testing of cells, nutrients and supplements, and mechanical impact on host disc cells that are maintained in their physiological surroundings (Fig. 4). In optimised bioreactor systems, caudal or lumbar discs from calf, sheep, or goat can be cultured under simulated physiological nutrition and loading conditions for up to several weeks without significant loss in cell viability. On the other hand, degenerative conditions can be simulated by restricting the nutrient supply, applying non-physiological load, or injuring the AF (Junger et al., 2009; Illien-Junger et al., 2010; Haglund et al., 2011; Paul et al., 2012; Illien-Junger et al., 2012). The limitations of explant cultures are that only acute effects can be evaluated and the whole range of interactions of local and systemic factors cannot be reproduced. Nevertheless, whole IVD bioreactors will significantly contribute to the reduction of animal experiments, as preliminary proof of concept studies can be performed in a controlled system 

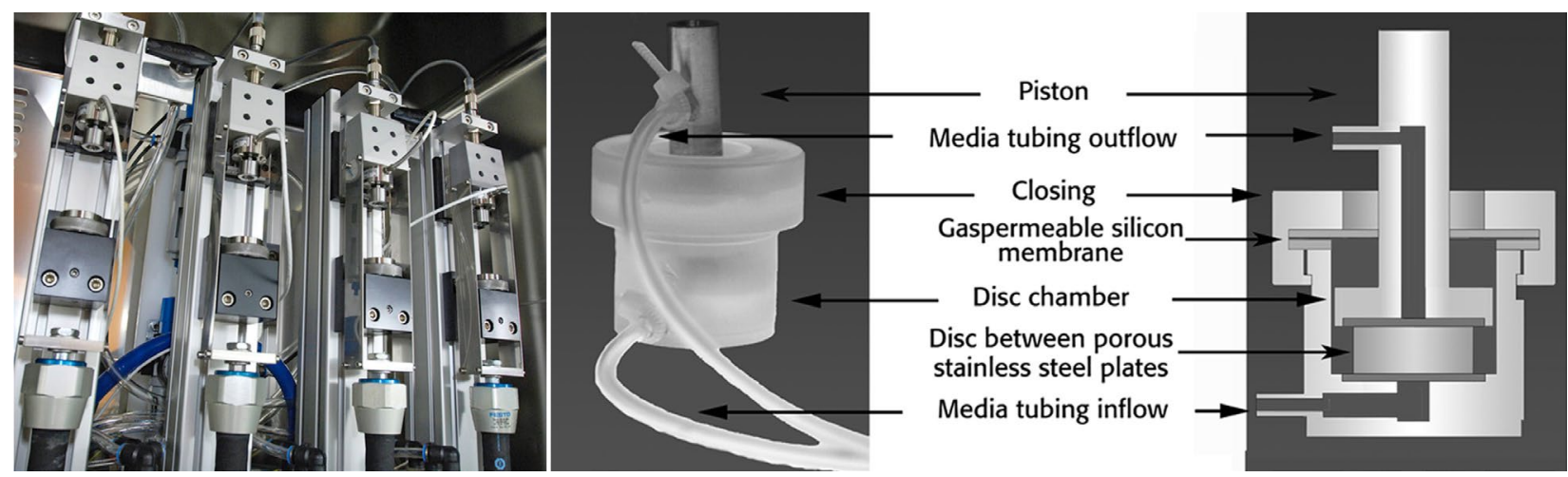

Fig. 4. Bioreactor system for culture of large animal (ovine/bovine) IVD. Four station loading device installed in a cell culture incubator (left), and polycarbonate chamber for culture of whole IVD with endplate designed to go with the loading system (right) (Junger et al., 2009; Illien-Junger et al., 2010).

prior to verifying an optimised biomaterial or cell therapy approach in vivo. Finally, the loading pattern not only can be precisely controlled, but may also be more relevant to the human condition than the load that is experienced in an animal disc in vivo.

\section{Conclusions}

Disorders related to back symptoms, including disc degeneration, low back pain and radiculopathy, are commonly not distinguished when economic considerations are addressed; it is therefore difficult to assess the economic impact of symptomatic disc herniation. Nonetheless, the health care costs, lost days at work, and decreased productivity account for an enormous economic burden. Back related conditions are a frequent cause of disability leading to annual health care costs of over $\$ 1$ billion in the USA. Health care spending on lumbar discectomies has been estimated to exceed $\$ 300$ million annually (Schoenfeld and Weiner, 2010).

Complementary or alternative surgical options would significantly improve the chances for the long-term benefit of discectomy procedures. Specifically, present surgical approaches to annulus repair are unsatisfactory, and novel strategies towards annular repair are needed. A substantial deficiency in the area of disc repair, which we aim to address, is the fragmented and often narrowly focused research efforts. We have established an interdisciplinary collaboration addressing biomaterial, biologic, mechanical and surgical needs. This consortium is run as a network of scientists working on the same clinical problem through different approaches. The inclusion of cellular and molecular signalling experts together with specialists in biomaterials, biomechanics, preclinical and clinical areas within the research program will add strength and complementary skills to the whole consortium. Contributions from all these areas are necessary to develop a biological construct which will, upon implantation, provide immediate closure of the defect and maintain the mechanical properties of the disc, while the cellular and biomolecular components will prevent further degeneration and enhance the endogenous regenerative process. Such an interdisciplinary approach is required to address the highly complex problem of providing an intra-operative procedure which could lead to reduced re-herniation of repaired AF tissue and decrease long term pain for patients.

\section{Acknowledgements}

The authors are supported by a consortium grant from AO Exploratory Research Board. J. C. Iatridis receives funding from NIAMS/NIH R01 AR057397 and C. C. Guterl from NIAMS/NIH F32 AR062455. We wish to confirm that there are no known conflicts of interest associated with this publication and there has been no significant financial support for this work that could have influenced its outcome.

\section{References}

Acaroglu ER, Iatridis JC, Setton LA, Foster RJ, Mow VC, Weidenbaum M (1995) Degeneration and aging affect the tensile behavior of human lumbar anulus fibrosus. Spine 20: 2690-2701.

Adams MA, McNally DS, Dolan P (1996) 'Stress' distributions inside intervertebral discs. The effects of age and degeneration. J Bone Joint Surg Br 78: 965-972.

Ahlgren BD, Lui W, Herkowitz HN, Panjabi MM, Guiboux JP (2000) Effect of anular repair on the healing strength of the intervertebral disc: a sheep model. Spine 25: $2165-2170$.

Alini M, Roughley PJ, Antoniou J, Stoll T, Aebi M (2002) A biological approach to treating disc degeneration: not for today, but maybe for tomorrow. Eur Spine J 11 Suppl 2: S215-S220.

Alini M, Li W, Markovic P, Aebi M, Spiro RC, Roughley PJ (2003) The potential and limitations of a cell-seeded collagen/hyaluronan scaffold to engineer an intervertebral disc-like matrix. Spine 28: 446-454.

Alini M, Eisenstein SM, Ito K, Little C, Kettler AA, Masuda K, Melrose J, Ralphs J, Stokes I, Wilke HJ (2008) Are animal models useful for studying human disc disorders/degeneration? Eur Spine J 17: 2-19. 
Andersson GB, Deyo RA (1996) History and physical examination in patients with herniated lumbar discs. Spine 21: 10S-18S.

Aoki Y, Akeda K, An H, Muehleman C, Takahashi K, Moriya H, Masuda K (2006) Nerve fiber ingrowth into scar tissue formed following nucleus pulposus extrusion in the rabbit anular-puncture disc degeneration model: effects of depth of puncture. Spine 31: E774-E780.

Atlas SJ, Deyo RA, Patrick DL, Convery K, Keller RB, Singer DE (1996) The Quebec Task Force classification for Spinal Disorders and the severity, treatment, and outcomes of sciatica and lumbar spinal stenosis. Spine 21: 28852892.

Attia M, Santerre JP, Kandel RA (2011) The response of annulus fibrosus cell to fibronectin-coated nanofibrous polyurethane-anionic dihydroxyoligomer scaffolds. Biomaterials 32: 450-460.

Bailey A, Messer J, Griffith SL (2010) Prospective, randomized controlled study of repairing the annulus fibrosus after lumbar discectomy: A single surgeon's experience. Tenth annual global symposium on motino preservation technology (SAS10), New Orleans, LA, abstract 208.

Bajanes G, Perez A, Diaz M (2007) One year follow up of discectomy patients who received a mesh to repair the annulus fibrosus. Spine Arthroplasty Society, Berlin, vol. 7.

Barth M, Diepers M, Weiss C, Thome C (2008) Two-year outcome after lumbar microdiscectomy versus microscopic sequestrectomy: part 2: radiographic evaluation and correlation with clinical outcome. Spine 33: 273-279.

Battie MC, Videman T (2006) Lumbar disc degeneration: epidemiology and genetics. J Bone Joint Surg Am 88 Suppl 2: 3-9.

Bergknut N, Rutges JP, Kranenburg HJ, Smolders LA, Hagman R, Smidt HJ, Lagerstedt AS, Penning LC, Voorhout G, Hazewinkel HA, Grinwis GC, Creemers LB, Meij BP, Dhert WJ (2012) The dog as an animal model for intervertebral disc degeneration? Spine 37: 351-358.

Berney J, Jeanpretre M, KostliA(1990) [Epidemiological factors of lumbar disk herniation]. Neurochirurgie 36: $354-$ 365.

Blankenbaker DG, Haughton VM, Rogers BP, Meyerand ME, Fine JP (2006) Axial rotation of the lumbar spinal motion segments correlated with concordant pain on discography: a preliminary study. Am J Roentgenol 186: 795-799.

Blaker JJ, Maquet V, Jerome R, Boccaccini AR, Nazhat SN (2005) Mechanical properties of highly porous PDLLA/Bioglass composite foams as scaffolds for bone tissue engineering. Acta Biomater 1: 643-652.

Blanco JF, Graciani IF, Sanchez-Guijo FM, Muntion S, Hernandez-Campo P, Santamaria C, Carrancio S, Barbado MV, Cruz G, Gutierrez-Cosio S, Herrero C, San Miguel JF, Brinon JG, del Canizo MC (2010) Isolation and characterization of mesenchymal stromal cells from human degenerated nucleus pulposus: comparison with bone marrow mesenchymal stromal cells from the same subjects. Spine 35: 2259-2265.
Bourgeault C, Beaubien B, Griffith S (2007) Biomechanical assessment of annulus fibrosus repair with suture tethered anchors. Spine Arthroplasty Society, Berlin, vol. 7.

Bowles RD, Williams RM, Zipfel WR, Bonassar LJ (2010) Self-assembly of aligned tissue-engineered annulus fibrosus and intervertebral disc composite via collagen gel contraction. Tissue Eng Part A 16: 1339-1348.

Bowles RD, Gebhard HH, Hartl R, Bonassar LJ (2011) Tissue-engineered intervertebral discs produce new matrix, maintain disc height, and restore biomechanical function to the rodent spine. Proc Natl Acad Sci USA 108: 1310613111.

Boyd LM, Richardson WJ, Allen KD, Flahiff C, Jing L, Li Y, Chen J, Setton LA (2008) Early-onset degeneration of the intervertebral disc and vertebral end plate in mice deficient in type IX collagen. Arthritis Rheum 58: 164-171.

Bron JL, Vonk LA, Smit TH, Koenderink GH (2011) Engineering alginate for intervertebral disc repair. J Mech Behav Biomed Mater 4: 1196-1205.

Bruehlmann SB, Rattner JB, Matyas JR, Duncan NA (2002) Regional variations in the cellular matrix of the annulus fibrosus of the intervertebral disc. J Anat 201: 159-171.

Carragee EJ, Alamin TF (2001) Discography. a review. Spine J 1: 364-372.

Carragee EJ, Han MY, Suen PW, Kim D (2003) Clinical outcomes after lumbar discectomy for sciatica: the effects of fragment type and anular competence. J Bone Joint Surg Am 85: 102-108.

Carragee EJ, Don AS, Hurwitz EL, Cuellar JM, Carrino JA, Herzog R (2009) 2009 ISSLS Prize Winner: Does discography cause accelerated progression of degeneration changes in the lumbar disc: a ten-year matched cohort study. Spine 34: 2338-2345.

Carrino JA, Lurie JD, Tosteson AN, Tosteson TD, Carragee EJ, Kaiser J, Grove MR, Blood E, Pearson LH, Weinstein JN, Herzog R (2009) Lumbar spine: reliability of MR imaging findings. Radiology 250: 161-170.

Chang G, Kim HJ, Kaplan D, Vunjak-Novakovic G, Kandel RA (2007) Porous silk scaffolds can be used for tissue engineering annulus fibrosus. Eur Spine J 16: 18481857.

Chen IR, Wie TS (2009) Disc height and lumbar index as independent predictors of degenerative spondylolisthesis in middle-aged women with low back pain. Spine 34: 1402-1409.

Chen J, Altman GH, Karageorgiou V, Horan R, Collette A, Volloch V, Colabro T, Kaplan DL (2003) Human bone marrow stromal cell and ligament fibroblast responses on RGD-modified silk fibers. J Biomed Mater Res A 67: 559570 .

Cheung KM, Karppinen J, Chan D, Ho DW, Song YQ, Sham P, Cheah KS, Leong JC, Luk KD (2009) Prevalence and pattern of lumbar magnetic resonance imaging changes in a population study of one thousand forty-three individuals. Spine 34: 934-940.

Chiang YF, Chiang CJ, Yang CH, Zhong ZC, Chen CS, Cheng CK, Tsuang YH (2012) Retaining intradiscal pressure after annulotomy by different annular suture 
techniques, and their biomechanical evaluations. Clin Biomech 27: 241-248.

Chiba K, Andersson GB, Masuda K, Thonar EJ (1997) Metabolism of the extracellular matrix formed by intervertebral disc cells cultured in alginate. Spine 22: 2885-2893.

Choi JH, Kim SH, Hong HK, Kim SJ, Lee SK, Kim OY, Park JH, Rhee JM, Khang G (2009) Regeneration of biodisc using annulus fibrosus cell on hyaluronic acid loaded PLGA scaffold. Tissue Eng Regen Med 6: 83-88.

Chujo T, An HS, Akeda K, Miyamoto K, Muehleman C, Attawia M, Andersson G, Masuda K (2006) Effects of growth differentiation factor-5 on the intervertebral discin vitro bovine study and in vivo rabbit disc degeneration model study. Spine 31: 2909-2917.

Clouet J, Grimandi G, Pot-Vaucel M, Masson M, Fellah HB, Guigand L, Cherel Y, Bord E, Rannou F, Weiss P, Guicheux J, Vinatier C (2009) Identification of phenotypic discriminating markers for intervertebral disc cells and articular chondrocytes. Rheumatology 48: 1447-1450.

Cole TC, Burkhardt D, Frost L, Ghosh P (1985) The proteoglycans of the canine intervertebral disc. Biochim Biophys Acta 839: 127-138.

Collin EC, Grad S, Zeugolis DI, Vinatier CS, Clouet JR, Guicheux JJ, Weiss P, Alini M, Pandit AS (2011) An injectable vehicle for nucleus pulposus cell-based therapy. Biomaterials 32: 2862-2870.

Coombes AG, Verderio E, Shaw B, Li X, Griffin M, Downes S (2002) Biocomposites of non-crosslinked natural and synthetic polymers. Biomaterials 23: 2113 2118.

Costi JJ, Stokes IA, Gardner-Morse M, Laible JP, Scoffone HM, Iatridis JC (2007) Direct measurement of intervertebral disc maximum shear strain in six degrees of freedom: motions that place disc tissue at risk of injury. $\mathrm{J}$ Biomech 40: 2457-2466.

Cs-Szabo G, Ragasa-San JD, Turumella V, Masuda K, Thonar EJ, An HS (2002) Changes in mRNA and protein levels of proteoglycans of the anulus fibrosus and nucleus pulposus during intervertebral disc degeneration. Spine 27: 2212-2219.

Dash BC, Mahor S, Carroll O, Mathew A, Wang W, Woodhouse KA, Pandit A (2011) Tunable elastin-like polypeptide hollow sphere as a high payload and controlled delivery gene depot. J Control Release 152: 382-392.

DePalma MJ, Ketchum JM, Saullo TR, Laplante BL (2012) Is the history of a surgical discectomy related to the source of chronic low back pain? Pain Physician 15: E53-E58.

Deyo RA, Weinstein JN (2001) Low back pain. N Engl J Med 344: 363-370.

Ekman P, Moller H, Shalabi A, Yu YX, Hedlund R (2009) A prospective randomised study on the long-term effect of lumbar fusion on adjacent disc degeneration. Eur Spine J 18: 1175-1186.

Ercelen O, Bulutcu E, Oktenoglu T, Sasani M, Bozkus H, Cetin SA, Ozer F (2003) Radiofrequency lesioning using two different time modalities for the treatment of lumbar discogenic pain: a randomized trial. Spine 28: 1922-1927.
Fazzalari NL, Costi JJ, Hearn TC, Fraser RD, VernonRoberts B, Hutchinson J, Manthey BA, Parkinson IH, Sinclair C (2001) Mechanical and pathologic consequences of induced concentric anular tears in an ovine model. Spine 26: 2575-2581.

Feng G, Yang X, Shang H, Marks IW, Shen FH, Katz A, Arlet V, Laurencin CT, Li X (2010) Multipotential differentiation of human anulus fibrosus cells: an in vitro study. J Bone Joint Surg Am 92: 675-685.

Freed LE, Vunjak-Novakovic G, Biron RJ, Eagles DB, Lesnoy DC, Barlow SK, Langer R (1994) Biodegradable polymer scaffolds for tissue engineering. Biotechnology 12: 689-693.

Freeman BJ, Fraser RD, Cain CM, Hall DJ, Chapple DC (2005) A randomized, double-blind, controlled trial: intradiscal electrothermal therapy versus placebo for the treatment of chronic discogenic low back pain. Spine 30: 2369-2377.

Freemont AJ, Peacock TE, Goupille P, Hoyland JA, O’Brien J, Jayson MI (1997) Nerve ingrowth into diseased intervertebral disc in chronic back pain. Lancet 350: 178181.

Fujiwara A, Lim TH, An HS, Tanaka N, Jeon CH, Andersson GB, Haughton VM (2000) The effect of disc degeneration and facet joint osteoarthritis on the segmental flexibility of the lumbar spine. Spine 25: 3036-3044.

Gilbertson L, Ahn SH, Teng PN, Studer RK, Niyibizi C, Kang JD (2008) The effects of recombinant human bone morphogenetic protein-2, recombinant human bone morphogenetic protein-12, and adenoviral bone morphogenetic protein-12 on matrix synthesis in human annulus fibrosis and nucleus pulposus cells. Spine J 8: 449-456.

Goel VK, Monroe BT, Gilbertson LG, Brinckmann P (1995) Interlaminar shear stresses and laminae separation in a disc. Finite element analysis of the L3-L4 motion segment subjected to axial compressive loads. Spine 20: 689-698.

Gore M, Sadosky A, Stacey BR, Tai KS, Leslie D (2012) The burden of chronic low back pain: clinical comorbidities, treatment patterns, and health care costs in usual care settings. Spine 37: E668-E677.

Grad S, Alini M, Eglin D, Sakai D, Mochida J, Mahor S, Collin E, Dash B, Pandit A (2010) Cells And Biomaterials For Intervertebral Disc Regeneration. Morgan \& Claypool Publishers, San Rafael, CA.

Gruber HE, Fisher EC, Jr., Desai B, Stasky AA, Hoelscher G, Hanley EN, Jr. (1997) Human intervertebral disc cells from the annulus: three-dimensional culture in agarose or alginate and responsiveness to TGF-beta1. Exp Cell Res 235: 13-21.

Gruber HE, Leslie K, Ingram J, Norton HJ, Hanley EN (2004) Cell-based tissue engineering for the intervertebral disc: in vitro studies of human disc cell gene expression and matrix production within selected cell carriers. Spine J 4: 44-55.

Gruber HE, Hoelscher GL, Leslie K, Ingram JA, Hanley EN, Jr. (2006) Three-dimensional culture of human disc cells within agarose or a collagen sponge: assessment of proteoglycan production. Biomaterials 27: 371-376. 
Gruber HE, Ingram J, Hoelscher GL, Norton HJ, Hanley EN, Jr. (2007a) Cell polarity in the anulus of the human intervertebral disc: morphologic, immunocytochemical, and molecular evidence. Spine 32: 1287-1294.

Gruber HE, Mougeot JL, Hoelscher G, Ingram JA, Hanley EN, Jr. (2007b) Microarray analysis of laser capture microdissected-anulus cells from the human intervertebral disc. Spine 32: 1181-1187.

Gruber HE, Hoelscher GL, Hanley EN, Jr. (2010) Annulus cells from more degenerated human discs show modified gene expression in 3D culture compared with expression in cells from healthier discs. Spine J 10: 721727.

Gruber HE, Watts JA, Hoelscher GL, Bethea SF, Ingram JA, Zinchenko NS, Hanley EN, Jr. (2011) Mitochondrial gene expression in the human annulus: in vivo data from annulus cells and selectively harvested senescent annulus cells. Spine J 11: 782-791.

Guilfoyle MR, Ganesan D, Seeley H, Laing RJ (2007) Prospective study of outcomes in lumbar discectomy. Br J Neurosurg 21: 389-395.

Guyot L, Griffith SL (2010) Re-operation rates after microdiscectomy with and without anular repair. Tenth annual global symposium on motion preservation technology (SAS10), New Orleans, LA, abstract 197.

Haglund L, Moir J, Beckman L, Mulligan KR, Jim B, Ouellet JA, Roughley P, Steffen T (2011) Development of a bioreactor for axially loaded intervertebral disc organ culture. Tissue Eng Part C Methods 17: 1011-1019.

Haughton VM, Rogers B, Meyerand ME, Resnick DK (2002) Measuring the axial rotation of lumbar vertebrae in vivo with MR imaging. Am J Neuroradiol 23: 1110-1116.

Hegewald AA, Neumann K, Kalwitz G, Freymann U, Endres M, Schmieder K, Kaps C, Thome C (2012) The chemokines CXCL10 and XCL1 recruit human annulus fibrosus cells. Spine 37: 101-107.

Helen W, Merry CL, Blaker JJ, Gough JE (2007) Three-dimensional culture of annulus fibrosus cells within PDLLA/Bioglass composite foam scaffolds: assessment of cell attachment, proliferation and extracellular matrix production. Biomaterials 28: 2010-2020.

Henriksson H, Thornemo M, Karlsson C, Hagg O, Junevik K, Lindahl A, Brisby H (2009) Identification of cell proliferation zones, progenitor cells and a potential stem cell niche in the intervertebral disc region: a study in four species. Spine 34: 2278-2287.

Henriksson HB, Svala E, Skioldebrand E, Lindahl A, Brisby H (2012) Support of concept that migrating progenitor cells from stem cell niches contribute to normal regeneration of the adult mammal intervertebral disc: a descriptive study in the New Zealand white rabbit. Spine 37: 722-732.

Heuer F, Schmidt H, Wilke HJ (2008a) Stepwise reduction of functional spinal structures increase disc bulge and surface strains. J Biomech 41: 1953-1960.

Heuer F, Ulrich S, Claes L, Wilke HJ (2008b) Biomechanical evaluation of conventional anulus fibrosus closure methods required for nucleus replacement. Laboratory investigation. J Neurosurg Spine 9: 307-313.
Hoogendoorn RJ, Helder MN, Kroeze RJ, Bank RA, Smit TH, Wuisman PI (2008) Reproducible long-term disc degeneration in a large animal model. Spine 33: 949-954.

Hoppe S, Quirbach S, Mamisch TC, Krause FG, Werlen S, Benneker LM (2012) Axial T2* mapping in intervertebral discs: a new technique for assessment of intervertebral disc degeneration. Eur Radiol 22: 2013-2019.

Hsieh AH, Hwang D, Ryan DA, Freeman AK, Kim H (2009) Degenerative anular changes induced by puncture are associated with insufficiency of disc biomechanical function. Spine 34: 998-1005.

Iatridis JC, ap Gwynn I (2004) Mechanisms for mechanical damage in the intervertebral disc annulus fibrosus. J Biomech 37: 1165-1175.

Iatridis JC, Kumar S, Foster RJ, Weidenbaum M, Mow VC (1999) Shear mechanical properties of human lumbar annulus fibrosus. J Orthop Res 17: 732-737.

Iatridis JC, Maclean JJ, Roughley PJ, Alini M (2006) Effects of mechanical loading on intervertebral disc metabolism in vivo. J Bone Joint Surg Am 88 Suppl 2: 41-46.

Iatridis JC, Setton LA, Foster RJ, Rawlins BA, Weidenbaum M, Mow VC (1998) Degeneration affects the anisotropic and nonlinear behaviors of human anulus fibrosus in compression. J Biomech 31: 535-544.

Illien-Junger S, Gantenbein-Ritter B, Grad S, Lezuo P, Ferguson SJ, Alini M, Ito K (2010) The combined effects of limited nutrition and high-frequency loading on intervertebral discs with endplates. Spine 35: 1744-1752.

Illien-Junger S, Pattappa G, Peroglio M, Benneker LM, Stoddart MJ, Sakai D, Mochida J, Grad S, Alini M (2012) Homing of mesenchymal stem cells in induced degenerative intervertebral discs in a whole organ culture system. Spine 37: 1865-1873.

Jackson AR, Yuan TY, Huang CY, Travascio F, Yong GW (2008) Effect of compression and anisotropy on the diffusion of glucose in annulus fibrosus. Spine 33: 1-7.

Jensen MC, Brant-Zawadzki MN, Obuchowski N, Modic MT, Malkasian D, Ross JS (1994a) Magnetic resonance imaging of the lumbar spine in people without back pain. N Engl J Med 331: 69-73.

Jensen MC, Kelly AP, Brant-Zawadzki MN (1994b) MRI of degenerative disease of the lumbar spine. Magn Reson Q 10: 173-190.

Johnson WE, Wootton A, El HA, Eisenstein SM, Curtis AS, Roberts S (2006) Topographical guidance of intervertebral disc cell growth in vitro: towards the development of tissue repair strategies for the anulus fibrosus. Eur Spine J 15 Suppl 3: S389-S396.

Johnson WE, Patterson AM, Eisenstein SM, Roberts S (2007) The presence of pleiotrophin in the human intervertebral disc is associated with increased vascularization: an immunohistologic study. Spine 32: 1295-1302.

Junger S, Gantenbein-Ritter B, Lezuo P, Alini M, Ferguson SJ, Ito K (2009) Effect of limited nutrition on in situ intervertebral disc cells under simulated-physiological loading. Spine 34: 1264-1271.

Kambin P, Cohen LF, Brooks M, Schaffer JL (1995) Development of degenerative spondylosis of the lumbar 
spine after partial discectomy. Comparison of laminotomy, discectomy, and posterolateral discectomy. Spine 20: 599607.

Kang CH, Kim YH, Lee SH, Derby R, Kim JH, Chung KB, Sung DJ (2009) Can magnetic resonance imaging accurately predict concordant pain provocation during provocative disc injection? Skeletal Radiol 38: 877-885.

Kim KS, Yoon ST, Li J, Park JS, Hutton WC (2005) Disc degeneration in the rabbit: a biochemical and radiological comparison between four disc injury models. Spine 30: 33-37.

Koepsell L, Zhang L, Neufeld D, Fong H, Deng Y (2011) Electrospun nanofibrous polycaprolactone scaffolds for tissue engineering of annulus fibrosus. Macromol Biosci 11: 391-399.

Kuh SU, Zhu Y, Li J, Tsai KJ, Fei Q, Hutton WC, Yoon TS (2009) A comparison of three cell types as potential candidates for intervertebral disc therapy: annulus fibrosus cells, chondrocytes, and bone marrow derived cells. Joint Bone Spine 76: 70-74.

Kvarstein G, Mawe L, Indahl A, Hol PK, Tennoe B, Digernes R, Stubhaug A, Tonnessen TI, Beivik H (2009) A randomized double-blind controlled trial of intra-annular radiofrequency thermal disc therapy--a 12-month followup. Pain 145: 279-286.

Le Visage C, Kim SW, Tateno K, Sieber AN, Kostuik JP, Leong KW (2006) Interaction of human mesenchymal stem cells with disc cells: changes in extracellular matrix biosynthesis. Spine 31: 2036-2042.

Lebow RL, Adogwa O, Parker SL, Sharma A, Cheng J, McGirt MJ (2011) Asymptomatic same-site recurrent disc herniation after lumbar discectomy: results of a prospective longitudinal study with 2-year serial imaging. Spine 36: 2147-2151.

Ledet EH, Jeshuran W, Glennon JC, Shaffrey C, De DP, Belden C, Kallakury B, Carl AL (2009) Small intestinal submucosa for anular defect closure: long-term response in an in vivo sheep model. Spine 34: 1457-1463.

Ledic D, Vilendecic M, Gorensek M, Varga P, Eustacchio S, Trummer M, Eskinja M, Einhorn J, Yeh O, Kamaric E, Lambrecht G (2007) Prospective controlled one-year clinical results on the intrinsic therapeutics Barricaid; a device for closing defects in the anulus. Spine J 7: 123S-124S.

Lee CR, Sakai D, Nakai T, Toyama K, Mochida J, Alini M, Grad S (2007) A phenotypic comparison of intervertebral disc and articular cartilage cells in the rat. Eur Spine J 16: 2174-2185.

Li X, Leo BM, Beck G, Balian G, Anderson GD (2004) Collagen and proteoglycan abnormalities in the GDF-5deficient mice and molecular changes when treating disk cells with recombinant growth factor. Spine 29: 2229-2234.

Liang H, Ma SY, Feng G, Shen FH, Joshua L, X (2010) Therapeutic effects of adenovirus-mediated growth and differentiation factor-5 in a mice disc degeneration model induced by annulus needle puncture. Spine J 10: 32-41.

Little JP, Adam CJ, Evans JH, Pettet GJ, Pearcy MJ (2007) Nonlinear finite element analysis of anular lesions in the L4/5 intervertebral disc. J Biomech 40: 2744-2751.
Liu LS, Thompson AY, Heidaran MA, Poser JW, Spiro RC (1999) An osteoconductive collagen/hyaluronate matrix for bone regeneration. Biomaterials 20: 1097-1108.

Liu LT, Huang B, Li CQ, Zhuang Y, Wang J, Zhou Y (2011) Characteristics of stem cells derived from the degenerated human intervertebral disc cartilage endplate. PLoS One 6: e26285.

Loupasis GA, Stamos K, Katonis PG, Sapkas G, Korres DS, Hartofilakidis G (1999) Seven- to 20-year outcome of lumbar discectomy. Spine 24: 2313-2317.

Maestretti G, Fuhrmann A, Ciarpaglini R (2012) Discal repair, first Swiss clinical experience with BarricaidTM. Proceedings of 30th Int. Symposium for Minimal Invasive Spine Surgery (ISMISS), Zurich, $\mathrm{CH}$.

Mahor S, Collin E, Dash BC, Pandit A (2011) Controlled release of plasmid DNA from hyaluronan nanoparticles. Curr Drug Deliv 8: 354-362.

Malandrino A, Noailly J, Lacroix D (2012) Regional annulus fibre orientations used as a tool for the calibration of lumbar intervertebral disc finite element models. Comput Methods Biomech Biomed Engin, in press (PMID:22224724).

Maldonado BA, Oegema TR, Jr. (1992) Initial characterization of the metabolism of intervertebral disc cells encapsulated in microspheres. J Orthop Res 10: 677690.

Maroudas A, Stockwell RA, Nachemson A, Urban J (1975) Factors involved in the nutrition of the human lumbar intervertebral disc: cellularity and diffusion of glucose in vitro. J Anat 120: 113-130.

Masuda K, Imai Y, Okuma M, Muehleman C, Nakagawa K, Akeda K, Thonar E, Andersson G, An HS (2006) Osteogenic protein-1 injection into a degenerated disc induces the restoration of disc height and structural changes in the rabbit anular puncture model. Spine 31: 742-754.

McGirt MJ, Eustacchio S, Varga P, Vilendecic M, Trummer M, Gorensek M, Ledic D, Carragee EJ (2009) A prospective cohort study of close interval computed tomography and magnetic resonance imaging after primary lumbar discectomy: factors associated with recurrent disc herniation and disc height loss. Spine 34: 2044-2051.

Mehra M, Hill K, Nicholl D, Schadrack J (2012) The burden of chronic low back pain with and without a neuropathic component: a healthcare resource use and cost analysis. J Med Econ 15: 245-252.

Melrose J, Roberts S, Smith S, Menage J, Ghosh $P$ (2002) Increased nerve and blood vessel ingrowth associated with proteoglycan depletion in an ovine anular lesion model of experimental disc degeneration. Spine 27: 1278-1285.

Melrose J, Smith SM, Fuller ES, Young AA, Roughley PJ, Dart A, Little CB (2007) Biglycan and fibromodulin fragmentation correlates with temporal and spatial annular remodelling in experimentally injured ovine intervertebral discs. Eur Spine J 16: 2193-2205.

Melrose J, Smith SM, Little CB, Moore RJ, VernonRoberts B, Fraser RD (2008) Recent advances in annular pathobiology provide insights into rim-lesion mediated 
intervertebral disc degeneration and potential new approaches to annular repair strategies. Eur Spine J 17: 1131-1148.

Melrose J, Shu C, Young C, Ho R, Smith MM, Young AA, Smith SS, Gooden B, Dart A, Podadera J, Appleyard RC, Little CB (2012) Mechanical destabilization induced by controlled annular incision of the intervertebral disc dysregulates metalloproteinase expression and induces disc degeneration. Spine 37: 18-25.

Michalek AJ, Iatridis JC (2012) Height and torsional stiffness are most sensitive to annular injury in large animal intervertebral discs. Spine J 12: 425-432.

Minogue BM, Richardson SM, Zeef LA, Freemont AJ, Hoyland JA (2010) Transcriptional profiling of bovine intervertebral disc cells: implications for identification of normal and degenerate human intervertebral disc cell phenotypes. Arthritis Res Ther 12: R22.

Mizuno H, Roy AK, Zaporojan V, Vacanti CA, Ueda M, Bonassar LJ (2006) Biomechanical and biochemical characterization of composite tissueengineered intervertebral discs. Biomaterials 27: 362-370.

Moore AJ, Chilton JD, Uttley D (1994a) Long-term results of microlumbar discectomy. Br J Neurosurg 8: 319-326.

Moore RJ, Latham JM, Vernon-Roberts B, Fraser RD (1994b) Does plate fixation prevent disc degeneration after a lateral anulus tear? Spine 19: 2787-2790.

Moutos FT, Freed LE, Guilak F (2007) A biomimetic three-dimensional woven composite scaffold for functional tissue engineering of cartilage. Nat Mater 6: 162-167.

Mwale F, Roughley P, Antoniou J (2004) Distinction between the extracellular matrix of the nucleus pulposus and hyaline cartilage: a requisite for tissue engineering of intervertebral disc. Eur Cell Mater 8: 58-63.

Mwale F, Ciobanu I, Giannitsios D, Roughley P, Steffen T, Antoniou J (2011) Effect of oxygen levels on proteoglycan synthesis by intervertebral disc cells. Spine 36: E131-E138.

Nachemson A (1966) The load on lumbar disks in different positions of the body. Clin Orthop Relat Res 45: 107-122.

Nasto LA, Seo HY, Robinson AR, Tilstra JS, Clauson CL, Sowa GA, Ngo K, Dong Q, Pola E, Lee JY, Niedernhofer LJ, Kang JD, Robbins PD, Vo NV (2012) ISSLS Prize Winner: Inhibition of NFkB activity ameliorates age-associated disc degeneration in a mouse model of accelerated aging. Spine 37: 1819-1825

Nerurkar NL, Elliott DM, Mauck RL (2007) Mechanics of oriented electrospun nanofibrous scaffolds for annulus fibrosus tissue engineering. J Orthop Res 25: 1018-1028.

Nerurkar NL, Baker BM, Sen S, Wible EE, Elliott DM, Mauck RL (2009) Nanofibrous biologic laminates replicate the form and function of the annulus fibrosus. Nat Mater 8: 986-992.

Nerurkar NL, Elliott DM, Mauck RL (2010) Mechanical design criteria for intervertebral disc tissue engineering. J Biomech 43: 1017-1030.

Nerurkar NL, Han W, Mauck RL, Elliott DM (2011a) Homologous structure-function relationships between native fibrocartilage and tissue engineered from MSCseeded nanofibrous scaffolds. Biomaterials 32: 461-468.
Nerurkar NL, Mauck RL, Elliott DM (2011b) Modeling interlamellar interactions in angle-ply biologic laminates for annulus fibrosus tissue engineering. Biomech Model Mechanobiol 10: 973-984.

Nesti LJ, Li WJ, Shanti RM, Jiang YJ, Jackson W, Freedman BA, Kuklo TR, Giuliani JR, Tuan RS (2008) Intervertebral disc tissue engineering using a novel hyaluronic acid-nanofibrous scaffold (HANFS) amalgam. Tissue Eng Part A 14: 1527-1537.

Noailly J, Ambrosio L, Elizabeth TK, Planell JA, Lacroix D (2012) In silico evaluation of a new composite disc substitute with a L3-L5 lumbar spine finite element model. Eur Spine J 21 Suppl 5: 675-687.

O’Connell GD, Vresilovic EJ, Elliott DM (2007) Comparison of animals used in disc research to human lumbar disc geometry. Spine 32: 328-333.

Orozco L, Soler R, Morera C, Alberca M, Sanchez A, Garcia-Sancho J (2011) Intervertebral disc repair by autologous mesenchymal bone marrow cells: a pilot study. Transplantation 92: 822-828.

Ortolani F, Raspanti M, Franchi M, Marchini M (1988) Localization of different alcian blue-proteoglycan particles in the intervertebral disc. Basic Appl Histochem 32: 443453.

Osti OL, Vernon-Roberts B, Fraser RD (1990) 1990 Volvo Award in experimental studies. Anulus tears and intervertebral disc degeneration. An experimental study using an animal model. Spine 15: 762-767.

Panjabi M, Brown M, Lindahl S, Irstam L, Hermens M (1988) Intrinsic disc pressure as a measure of integrity of the lumbar spine. Spine 13: 913-917.

Parker SL, Xu R, McGirt MJ, Witham TF, Long DM, Bydon A (2010) Long-term back pain after a single-level discectomy for radiculopathy: incidence and health care cost analysis. J Neurosurg Spine 12: 178-182.

Paul CP, Zuiderbaan HA, Zandieh DB, van der Veen AJ, van de Ven PM, Smit TH, Helder MN, van Royen BJ, Mullender MG (2012) Simulated-physiological loading conditions preserve biological and mechanical properties of caprine lumbar intervertebral discs in ex vivo culture. PLoS One 7: e33147.

Pauza KJ, Howell S, Dreyfuss P, Peloza JH, Dawson K, Bogduk N (2004) A randomized, placebo-controlled trial of intradiscal electrothermal therapy for the treatment of discogenic low back pain. Spine J 4: 27-35.

Pope MH, Magnusson M, Wilder DG (1998) Kappa Delta Award. Low back pain and whole body vibration. Clin Orthop Relat Res 354: 241-248.

Power KA, Grad S, Rutges JP, Creemers LB, van Rijen MH, O’Gaora P, Wall JG, Alini M, Pandit A, Gallagher WM (2011) Identification of cell surface-specific markers to target human nucleus pulposus cells: expression of carbonic anhydrase XII varies with age and degeneration. Arthritis Rheum 63: 3876-3886.

Rethore G, Mathew A, Naik H, Pandit A (2009) Preparation of chitosan/polyglutamic acid spheres based on the use of polystyrene template as a nonviral gene carrier. Tissue Eng Part C Methods 15: 605-613.

Risbud MV, Guttapalli A, Tsai TT, Lee JY, Danielson KG, Vaccaro AR, Albert TJ, Gazit Z, Gazit D, Shapiro IM (2007) Evidence for skeletal progenitor cells in the 
degenerate human intervertebral disc. Spine 32: $2537-$ 2544.

Roberts S, Evans H, Trivedi J, Menage J (2006) Histology and pathology of the human intervertebral disc. J Bone Joint Surg Am 88 Suppl 2: 10-14.

Rong Y, Sugumaran G, Silbert JE, Spector M (2002) Proteoglycans synthesized by canine intervertebral disc cells grown in a type I collagen-glycosaminoglycan matrix. Tissue Eng 8: 1037-1047.

Roughley PJ (2004) Biology of intervertebral disc aging and degeneration: involvement of the extracellular matrix. Spine 29: 2691-2699.

Rutges J, Creemers LB, Dhert W, Milz S, Sakai D, Mochida J, Alini M, Grad S (2010) Variations in gene and protein expression in human nucleus pulposus in comparison with annulus fibrosus and cartilage cells: potential associations with aging and degeneration. Osteoarthritis Cartilage 18: 416-423.

Saad L, Spector M (2004) Effects of collagen type on the behavior of adult canine annulus fibrosus cells in collagen-glycosaminoglycan scaffolds. J Biomed Mater Res A 71: 233-241.

Sachs BL, Vanharanta H, Spivey MA, Guyer RD, Videman T, Rashbaum RF, Johnson RG, Hochschuler SH, Mooney V (1987) Dallas discogram description. A new classification of CT/discography in low-back disorders. Spine 12: 287-294.

Sakai D, Mochida J, Yamamoto Y, Nomura T, Okuma M, Nishimura K, Nakai T, Ando K, Hotta T (2003) Transplantation of mesenchymal stem cells embedded in Atelocollagen gel to the intervertebral disc: a potential therapeutic model for disc degeneration. Biomaterials 24: 3531-3541.

Sakai D, Mochida J, Iwashina T, Hiyama A, Omi H, Imai M, Nakai T, Ando K, Hotta T (2006) Regenerative effects of transplanting mesenchymal stem cells embedded in atelocollagen to the degenerated intervertebral disc. Biomaterials 27: 335-345.

Sakai D, Nakai T, Mochida J, Alini M, Grad S (2009) Differential phenotype of intervertebral disc cells: microarray and immunohistochemical analysis of canine nucleus pulposus and anulus fibrosus. Spine 34: 14481456.

Santerre JP, Woodhouse K, Laroche G, Labow RS (2005) Understanding the biodegradation of polyurethanes: from classical implants to tissue engineering materials. Biomaterials 26: 7457-7470.

Sato M, Asazuma T, Ishihara M, Kikuchi T, Masuoka K, Ichimura S, Kikuchi M, Kurita A, Fujikawa K (2003a) An atelocollagen honeycomb-shaped scaffold with a membrane seal (ACHMS-scaffold) for the culture of annulus fibrosus cells from an intervertebral disc. J Biomed Mater Res A 64: 248-256.

Sato M, Kikuchi M, Ishihara M, Ishihara M, Asazuma T, Kikuchi T, Masuoka K, Hattori H, Fujikawa K (2003b) Tissue engineering of the intervertebral disc with cultured annulus fibrosus cells using atelocollagen honeycombshaped scaffold with a membrane seal (ACHMS scaffold). Med Biol Eng Comput 41: 365-371.

Schmidt H, Heuer F, Simon U, Kettler A, Rohlmann A, Claes L, Wilke HJ (2006) Application of a new calibration method for a three-dimensional finite element model of a human lumbar annulus fibrosus. Clin Biomech 21: 337344.

Schmidt H, Kettler A, Rohlmann A, Claes L, Wilke HJ (2007) The risk of disc prolapses with complex loading in different degrees of disc degeneration - a finite element analysis. Clin Biomech 22: 988-998.

Schneider TO, Mueller SM, Shortkroff S, Spector M (1999) Expression of alpha-smooth muscle actin in canine intervertebral disc cells in situ and in collagenglycosaminoglycan matrices in vitro. J Orthop Res 17: 192-199.

Schoenfeld AJ, Weiner BK (2010) Treatment of lumbar disc herniation: Evidence-based practice. Int J Gen Med 3: 209-214.

Schollum ML, Robertson PA, Broom ND (2010) How age influences unravelling morphology of annular lamellae - a study of interfibre cohesivity in the lumbar disc. J Anat 216: 310-319.

See EY, Toh SL, Goh JC (2011) Effects of radial compression on a novel simulated intervertebral disc-like assembly using bone marrow-derived mesenchymal stem cell cell-sheets for annulus fibrosus regeneration. Spine 36: 1744-1751.

Sha'ban M, Kim SH, Idrus RB, Khang G (2008a) Fibrin and poly(lactic-co-glycolic acid) hybrid scaffold promotes early chondrogenesis of articular chondrocytes: an in vitro study. J Orthop Surg Res 3: 17.

Sha'ban M, Yoon SJ, Ko YK, Ha HJ, Kim SH, So JW, Idrus RB, Khang G (2008b) Fibrin promotes proliferation and matrix production of intervertebral disc cells cultured in three-dimensional poly(lactic-co-glycolic acid) scaffold. J Biomater Sci Polym Ed 19: 1219-1237.

Shao X, Hunter CJ (2007) Developing an alginate/ chitosan hybrid fiber scaffold for annulus fibrosus cells. J Biomed Mater Res A 82: 701-710.

Sherwood JK, Riley SL, Palazzolo R, Brown SC, Monkhouse DC, Coates M, Griffith LG, Landeen LK, Ratcliffe A (2002) A three-dimensional osteochondral composite scaffold for articular cartilage repair. Biomaterials 23: 4739-4751.

Shirazi-Adl A (1989) Strain in fibers of a lumbar disc. Analysis of the role of lifting in producing disc prolapse. Spine 14: 96-103.

Showalter BL, Beckstein JC, Martin JT, Beattie EE, Orias AA, Schaer TP, Vresilovic EJ, Elliott DM (2012) Comparison of animal discs used in disc research to human lumbar disc: torsion mechanics and collagen content. Spine 37: E900-E907.

Singh K, Masuda K, Thonar EJ, An HS, Cs-Szabo G (2009) Age-related changes in the extracellular matrix of nucleus pulposus and anulus fibrosus of human intervertebral disc. Spine 34: 10-16.

Sobajima S, Kompel JF, Kim JS, Wallach CJ, Robertson DD, Vogt MT, Kang JD, Gilbertson LG (2005) A slowly progressive and reproducible animal model of intervertebral disc degeneration characterized by MRI, X-ray, and histology. Spine 30: 15-24.

Spengler DM, Ouellette EA, Battie M, Zeh J (1990) Elective discectomy for herniation of a lumbar disc. 
Additional experience with an objective method. J Bone Joint Surg Am 72: 230-237.

Stadnik TW, Lee RR, Coen HL, Neirynck EC, Buisseret TS, Osteaux MJ (1998) Annular tears and disk herniation: prevalence and contrast enhancement on MR images in the absence of low back pain or sciatica. Radiology 206: 49-55.

Stokes IA, Iatridis JC (2004) Mechanical conditions that accelerate intervertebral disc degeneration: overload versus immobilization. Spine 29: 2724-2732.

Suk KS, Lee HM, Moon SH, Kim NH (2001) Recurrent lumbar disc herniation: results of operative management. Spine 26: 672-676.

Takahashi K, Aoki Y, Ohtori S (2008) Resolving discogenic pain. Eur Spine J 17 Suppl 4: 428-431.

Thompson RE, Pearcy MJ, Downing KJ, Manthey BA, Parkinson IH, Fazzalari NL (2000) Disc lesions and the mechanics of the intervertebral joint complex. Spine 25: 3026-3035.

Urban JP, Smith S, Fairbank JC (2004) Nutrition of the intervertebral disc. Spine 29: 2700-2709.

Vadala G, Sowa G, Hubert M, Gilbertson LG, Denaro V, Kang JD (2012) Mesenchymal stem cells injection in degenerated intervertebral disc: cell leakage may induce osteophyte formation. J Tissue Eng Regen Med 6: 348-355.

Veres SP, Robertson PA, Broom ND (2008) ISSLS prize winner: microstructure and mechanical disruption of the lumbar disc annulus: part II: how the annulus fails under hydrostatic pressure. Spine 33: 2711-2720.

Vernon-Roberts B, Moore RJ, Fraser RD (2007) The natural history of age-related disc degeneration: the pathology and sequelae of tears. Spine 32: 2797-2804.

Vucetic N, de Bri E, Svensson O (1997) Clinical history in lumbar disc herniation. A prospective study in 160 patients. Acta Orthop Scand 68: 116-120.

Wan Y, Feng G, Shen FH, Balian G, Laurencin CT, Li X (2007) Novel biodegradable poly(1,8-octanediol malate) for annulus fibrosus regeneration. Macromol Biosci 7: 1217-1224.

Wan Y, Feng G, Shen FH, Laurencin CT, Li X (2008) Biphasic scaffold for annulus fibrosus tissue regeneration. Biomaterials 29: 643-652.

Wang Z, Li H (2005) A novel 3D finite element modeling based on medical image for intervertebral disc biomechanical analysis. Conf Proc IEEE Eng Med Biol Soc 3: 3202-3205.

Wang YH, Kuo TF, Wang JL (2007) The implantation of non-cell-based materials to prevent the recurrent disc herniation: an in vivo porcine model using quantitative discomanometry examination. Eur Spine J 16: 1021-1027.

Watanabe A, Benneker LM, Boesch C, Watanabe T, Obata T, Anderson SE (2007) Classification of intervertebral disk degeneration with axial T2 mapping. Am J Roentgenol 189: 936-942.

Weber H (1983) Lumbar disc herniation. A controlled, prospective study with ten years of observation. Spine 8: 131-140.

Weber H (1994) The natural history of disc herniation and the influence of intervention. Spine 19: 2234-2238.

Wee S, Gombotz WR (1998) Protein release from alginate matrices. Adv Drug Deliv Rev 31: 267-285.
Wei A, Tao H, Chung SA, Brisby H, Ma DD, Diwan AD (2009a) The fate of transplanted xenogeneic bone marrow-derived stem cells in rat intervertebral discs. J Orthop Res 27: 374-379.

Wei A, Williams LA, Bhargav D, Shen B, Kishen T, Duffy N, Diwan AD (2009b) BMP13 prevents the effects of annular injury in an ovine model. Int J Biol Sci 5: 388396.

Weinstein JN, Lurie JD, Olson PR, Bronner KK, Fisher ES (2006a) United States' trends and regional variations in lumbar spine surgery: 1992-2003. Spine 31: 2707-2714.

Weinstein JN, Lurie JD, Tosteson TD, Skinner JS, Hanscom B, Tosteson AN, Herkowitz H, Fischgrund J, Cammisa FP, Albert T, Deyo RA (2006b) Surgical vs nonoperative treatment for lumbar disk herniation: the Spine Patient Outcomes Research Trial (SPORT) observational cohort. JAMA 296: 2451-2459.

Weinstein JN, Lurie JD, Tosteson TD, Tosteson AN, Blood EA, Abdu WA, Herkowitz H, Hilibrand A, Albert T, Fischgrund J (2008) Surgical versus nonoperative treatment for lumbar disc herniation: four-year results for the Spine Patient Outcomes Research Trial (SPORT). Spine 33: 2789-2800.

Wilda H, Gough JE (2006) In vitro studies of annulus fibrosus disc cell attachment, differentiation and matrix production on PDLLA/45S5 Bioglass composite films. Biomaterials 27: 5220-5229.

Wilke HJ, Neef P, Caimi M, Hoogland T, Claes LE (1999) New in vivo measurements of pressures in the intervertebral disc in daily life. Spine 24: 755-762.

Williams FM, Sambrook PN (2011) Neck and back pain and intervertebral disc degeneration: role of occupational factors. Best Pract Res Clin Rheumatol 25: 69-79.

Wuertz K, Godburn K, Maclean JJ, Barbir A, Donnelly JS, Roughley PJ, Alini M, Iatridis JC (2009) In vivo remodeling of intervertebral discs in response to short- and long-term dynamic compression. J Orthop Res 27: 1235 1242.

Wuertz K, Vo N, Kletsas D, Boos N (2012) Inflammatory and catabolic signalling in intervertebral discs: the roles of NF-kappaB and MAP kinases. Eur Cell Mater 23: 103-119.

Yang L, Kandel RA, Chang G, Santerre JP (2009) Polar surface chemistry of nanofibrous polyurethane scaffold affects annulus fibrosus cell attachment and early matrix accumulation. J Biomed Mater Res A 91: 1089-1099.

Yannas IV, Lee E, Orgill DP, Skrabut EM, Murphy GF (1989) Synthesis and characterization of a model extracellular matrix that induces partial regeneration of adult mammalian skin. Proc Natl Acad Sci USA 86: 933937.

Yoon ST, Park JS, Kim KS, Li J, Attallah-Wasif ES, Hutton WC, Boden SD (2004) ISSLS prize winner: LMP-1 upregulates intervertebral disc cell production of proteoglycans and BMPs in vitro and in vivo. Spine 29: 2603-2611.

Yoon SH, Miyazaki M, Hong SW, Tow B, Morishita Y, Hu M, Ahn SJ, Wang JC (2008) A porcine model of intervertebral disc degeneration induced by annular injury characterized with magnetic resonance imaging and histopathological findings. Laboratory investigation. J Neurosurg Spine 8: 450-457. 
Yorimitsu E, Chiba K, Toyama Y, Hirabayashi K (2001) Long-term outcomes of standard discectomy for lumbar disc herniation: a follow-up study of more than 10 years. Spine 26: 652-657.

Yu SW, Sether LA, Ho PS, Wagner M, Haughton VM (1988) Tears of the anulus fibrosus: correlation between MR and pathologic findings in cadavers. Am J Neuroradiol 9: 367-370.

Yu J, Tirlapur U, Fairbank J, Handford P, Roberts S, Winlove CP, Cui Z, Urban J (2007) Microfibrils, elastin fibres and collagen fibres in the human intervertebral disc and bovine tail disc. J Anat 210: 460-471.

Yurube T, Takada T, Suzuki T, Kakutani K, Maeno K, Doita M, Kurosaka M, Nishida K (2012) Rat tail static compression model mimics extracellular matrix metabolic imbalances of matrix metalloproteinases, aggrecanases, and tissue inhibitors of metalloproteinases in intervertebral disc degeneration. Arthritis Res Ther 14: R51.

Zhang Y, Anderson DG, Phillips FM, Thonar EJ, He TC, Pietryla D, An HS (2007) Comparative effects of bone morphogenetic proteins and Sox 9 overexpression on matrix accumulation by bovine anulus fibrosus cells: implications for anular repair. Spine 32: 2515-2520.

Zhang Y, Markova D, Im HJ, Hu W, Thonar EJ, He TC, An HS, Phillips FM, Anderson DG (2009) Primary bovine intervertebral disc cells transduced with adenovirus overexpressing 12 BMPs and Sox9 maintain appropriate phenotype. Am J Phys Med Rehabil 88: 455-463.

Zhang H, Yang S, Wang L, Park P, La MF, Hollister SJ, Lin CY (2011a) Time course investigation of intervertebral disc degeneration produced by needle-stab injury of the rat caudal spine: laboratory investigation. J Neurosurg Spine 15: 404-413.

Zhang Y, Drapeau S, An HS, Markova D, Lenart BA, Anderson DG (2011b) Histological features of the degenerating intervertebral disc in a goat disc-injury model. Spine 36: 1519-1527.
Zhang Y, Drapeau S, Howard SA, Thonar EJ, Anderson DG (2011c) Transplantation of goat bone marrow stromal cells to the degenerating intervertebral disc in a goat disc injury model. Spine 36: 372-377.

Zhang YH, Zhao CQ, Jiang LS, Dai LY (2011d) Lentiviral shRNA silencing of CHOP inhibits apoptosis induced by cyclic stretch in rat annular cells and attenuates disc degeneration in the rats. Apoptosis 16: 594-605.

Zobel BB, Vadala G, Vescovo RD, Battisti S, Martina FM, Stellato L, Leoncini E, Borthakur A, Denaro V (2012) T1rho magnetic resonance imaging quantification of early lumbar intervertebral disc degeneration in healthy young adults. Spine 37: 1224-1230.

\section{Discussion with Reviewers}

Reviewer II: Does the existing data support the need to replicate the native tissue structure, or native tissue biochemistry, in identifying a suitable AF repair?

Authors: It is generally recognised that in load-bearing tissues an interrelation between composition, structure and function exists. A number of in vitro studies have demonstrated that close replication of the structural organisation of the native AF is beneficial for the phenotype of incorporated cells, the accumulation of appropriate matrix molecules, and the mechanical properties of a tissue engineered construct. These data provide substantial evidence for the success of such systems in vivo. However, to date there is no clinical or pre-clinical in vivo data available that clearly indicate to what extent the natural composition and/or structure is needed to support long term AF repair. Large animal in vivo studies and eventually clinical studies will be necessary to ultimately corroborate the importance of the implant design for functional AF repair. 